Pego 1 of 2 Proj.

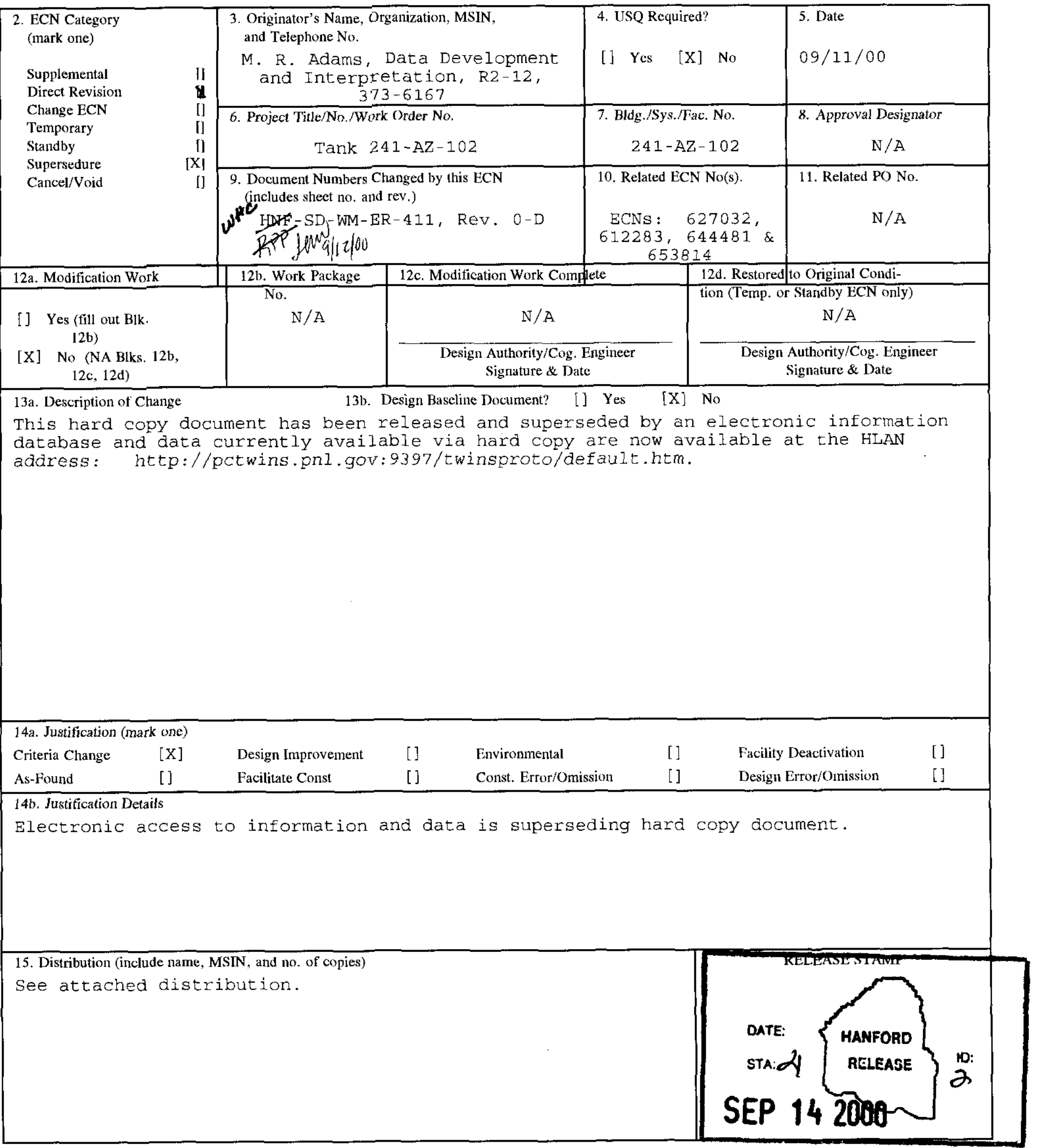




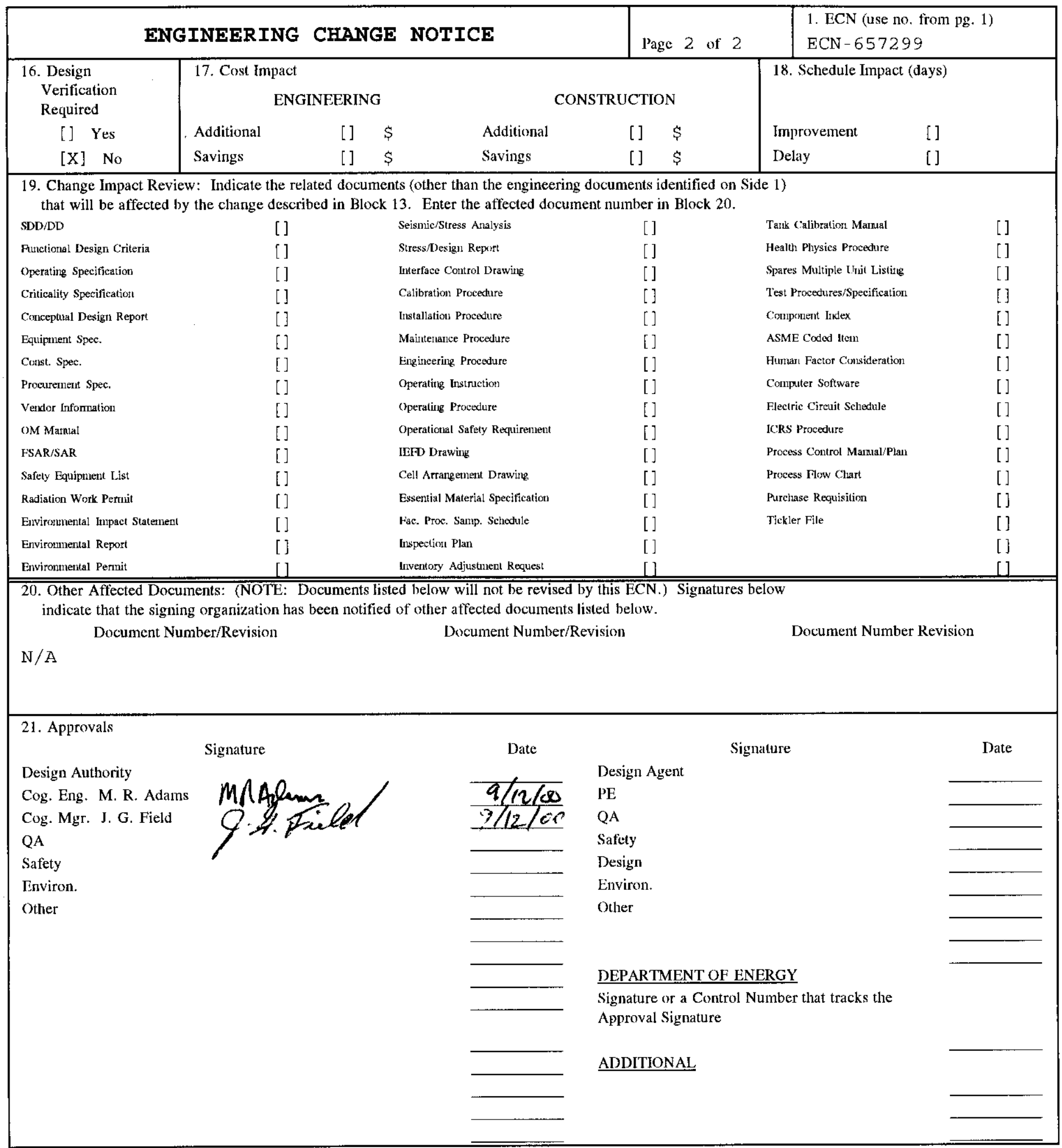




\section{DISTRIBUTION SHEET}

\begin{tabular}{|c|c|c|c|c|c|}
\hline \multirow[b]{2}{*}{ Distribution } & \multirow{2}{*}{\multicolumn{3}{|c|}{$\begin{array}{c}\text { Data Development a } \\
\text { Interpretation }\end{array}$}} & \multicolumn{2}{|c|}{ Page 1 of 2} \\
\hline & & & & Date & $09 / 11 / 00$ \\
\hline \multicolumn{4}{|l|}{ Project Title/work Order } & \multicolumn{2}{|c|}{ EDT No. N/A } \\
\hline $\begin{array}{ll}\text { RPP-SD-WM-ER-4Il, Rev. 1, "Tank } \\
\text { Double-Shell Tank } 241-\mathrm{AZ}-102 \text { " }\end{array}$ & \multicolumn{3}{|c|}{ Characterization Report for } & \multicolumn{2}{|c|}{ ECN No. 657299} \\
\hline Name & MSIN & $\begin{array}{c}\text { Text } \\
\text { With } \\
\text { All } \\
\text { Attach. }\end{array}$ & $\begin{array}{l}\text { Text } \\
\text { Only }\end{array}$ & $\begin{array}{l}\text { Attach./ } \\
\text { Appendix } \\
\text { Only }\end{array}$ & $\begin{array}{l}\mathrm{EDT} / \mathrm{ECN} \\
\text { Only }\end{array}$ \\
\hline
\end{tabular}

OFFSITE

Sandia National Laboratory

P.O. BoX 5800

MS-0744, Dept. 6404

Albuquerque, NM 87815

D. Powers

$\mathrm{X}$

Nuclear Consulting Services Inc.

P. O. Box 29151

Columbus, OH 43229-01051

J. L. Kovach

$\mathrm{x}$

Chemical Reaction Sub-TAP

P.O. Box 271

Lindsborg, KS 67456

B. C. Hudson

$\mathrm{X}$

SAIC

555 Quince Orchard Rd., Suite 500

Gaithersburg, MD 20878-1437

H. Sutter

$\mathrm{X}$

Los Alamos Laboratory

CST-14 MS-J58 6

P. O. Box 1663

Los Alamos, NM 87545

S. F. Agnew

$\mathrm{x}$

Tank Advisory Panel

102 Windham Road

Oak Ridge, TN 37830

D. O. Campbell

$\mathrm{X}$ 


\section{DISTRIBUTION SHEET}

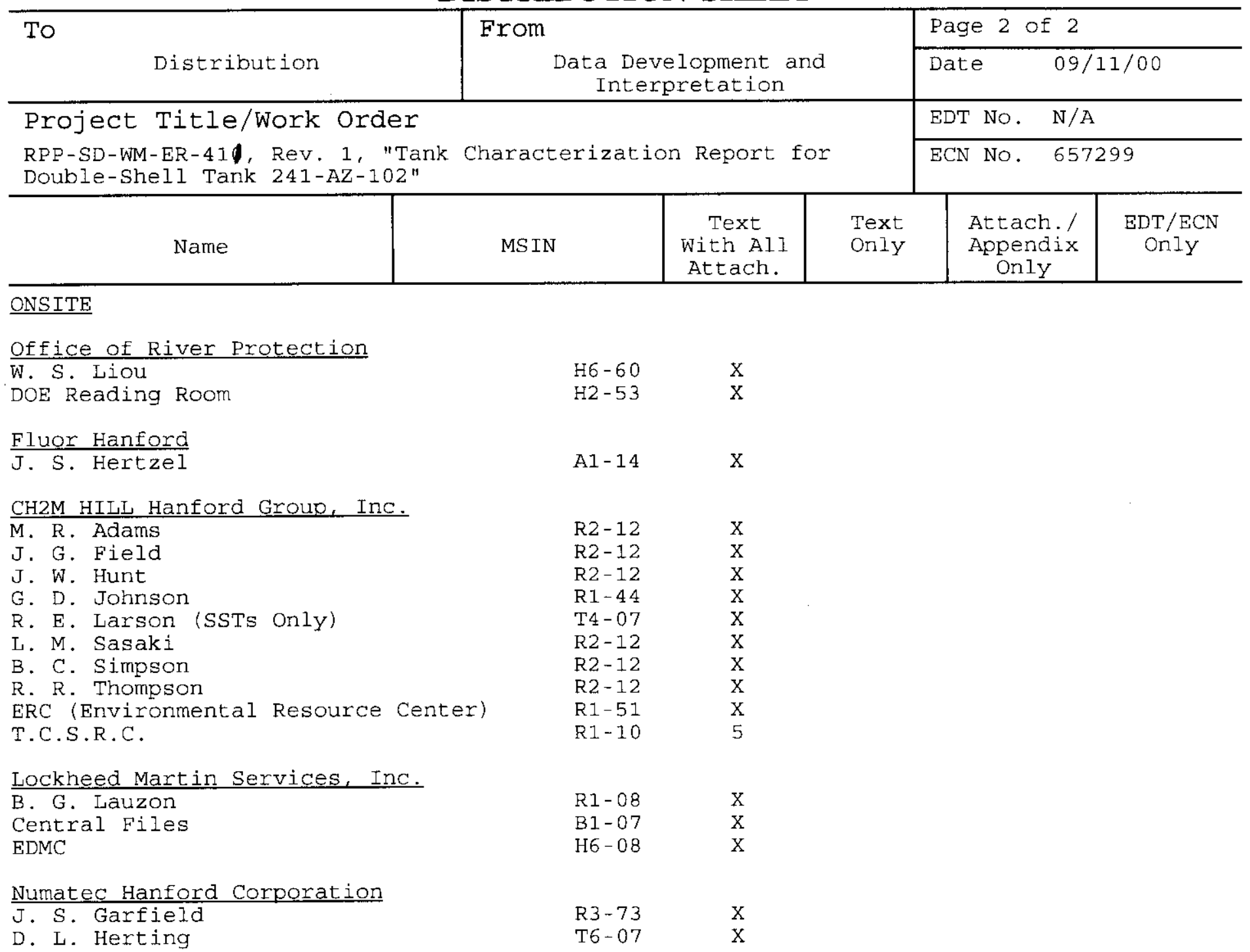




\title{
Tank Characterization Report for Double-Shell Tank 241-AZ-102
}

\author{
Melvin R. Adams \\ Lockheed Martin Hanford Corp., Richland, WA 99352 \\ Office of River Protection Contract DE-AC06-99RL14047 \\ $\mathrm{EDT} / \mathrm{ECN}: \quad \mathrm{ECN}-653814 \quad \mathrm{UC}: 2070$ \\ Org Code: 74B20 CACN/COA: 102217/EI00 \\ B\&R Code: EW 3120074 Total Pages: 37 \\ Key Words: Waste Characterization, Double-Shell Tank, DST, Tank 241-AZ- \\ 102, Tank AZ-102, AZ-102, AZ Farm, Tank Characterization Report, TCR, \\ Waste Inventory, TPA Milestone M-44 \\ Abstract: N/A
}

TRADEMARK DISCLAIMER. Reference herein to any specific commercial product, process, or service by trade name, trademark, manufacturer, or otherwise, does not necessarily constitute or imply its endorsement, recommendation, or favoring by the United States Government or any agency thereof or its contractors or subcontractors.

Printed in the United States of America. To obtain copies of this document, contact: WHC/BCS Document Control Services, P.O. Box 1970, Mailstop H6-08, Richland WA 99352, Phone (509) 372-2420.5averand 376 -4080
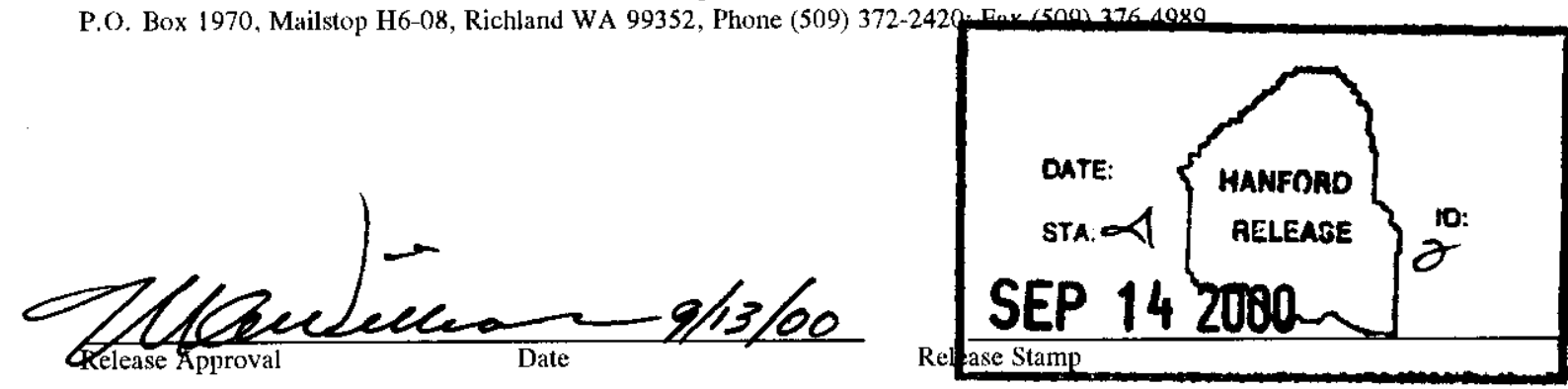

\section{Approved for Public Release}




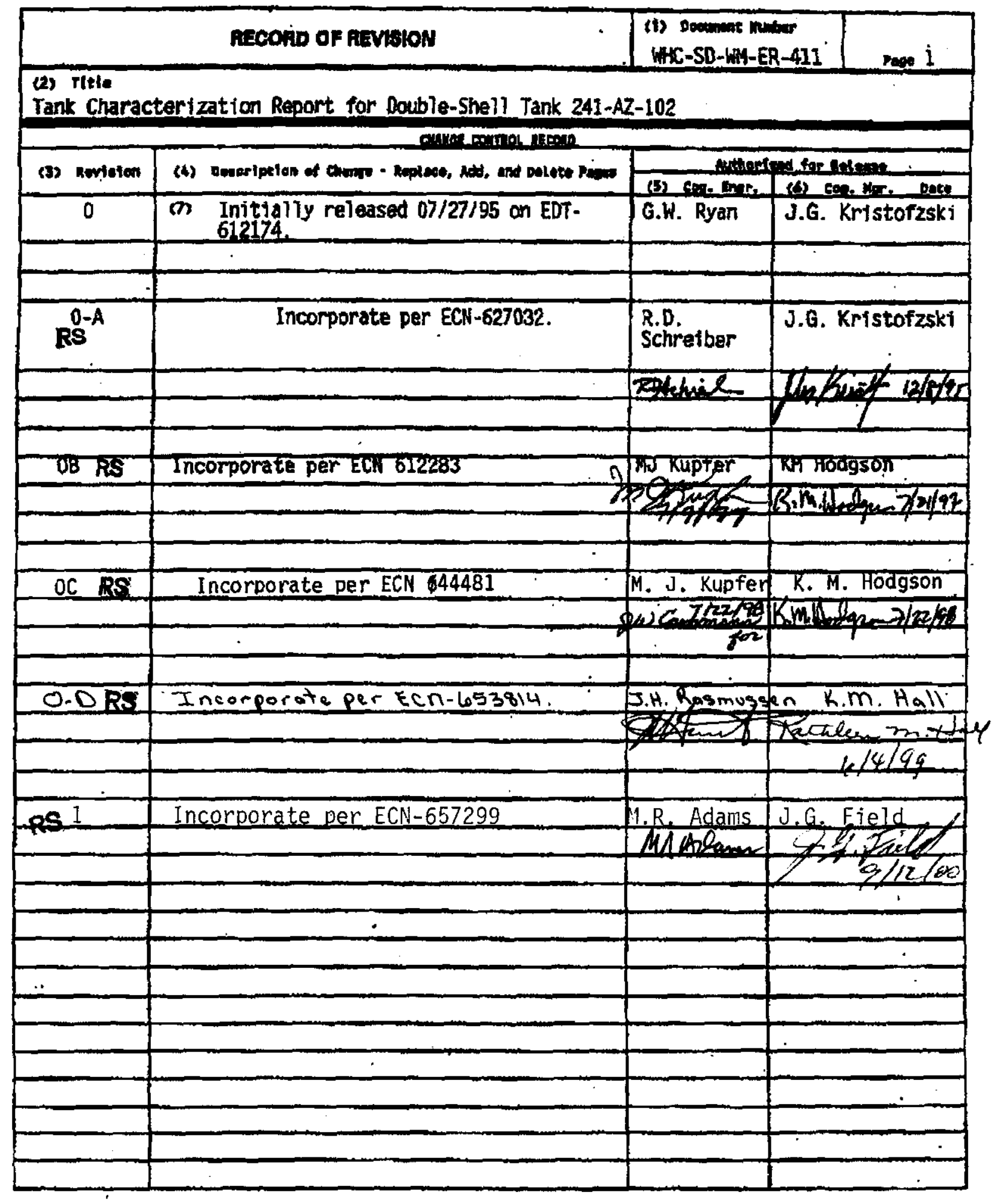

A-7520-00s cosens untas 
Some of the reports herein may contain data that has not been reviewed or edited. The data will have been reviewed or edited as of the date that a Tank Interpretive Report (TIR) is prepared and approved. The TIR for this tank was approved on September 8, 2000.

Tank: 241-AZ-102

Sampling Events:

254

261

262

268

AZ1021

AZ1022

AZ1023

Reports:

Tank Interpretive Report

Constituent Groups:

Anions

Inorganics

Metals/Nonmetals

Organics

PCBs

Physical Properties

Radionuclides 


\section{RPP-SD-WM-ER-411, Rev. 1}

Table of Contents

Data Dictionary to Reports in this Document ................................................ 1

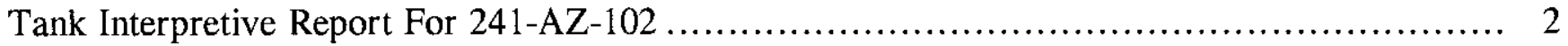

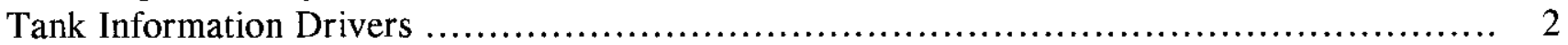

Table 1-2. Non-Volatile Elements From Core 262 in Comparison to Envelope D Limits ...... 4

Table 1-3. Volatile Components From Core 262 in Comparison to Envelope D Limits ....... 5

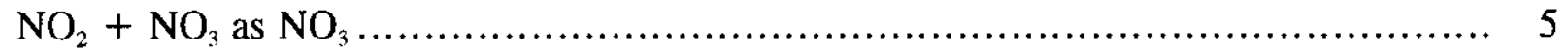

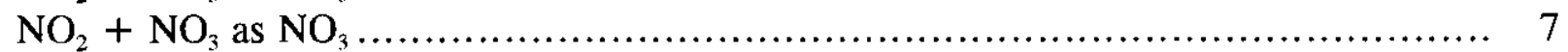

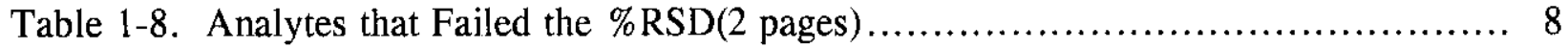

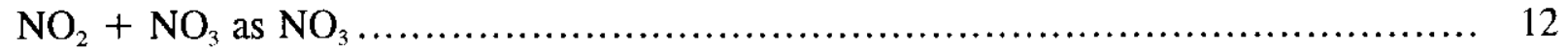

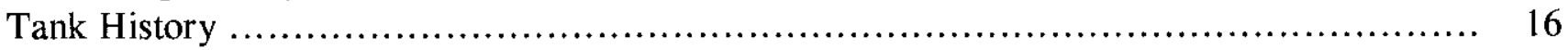

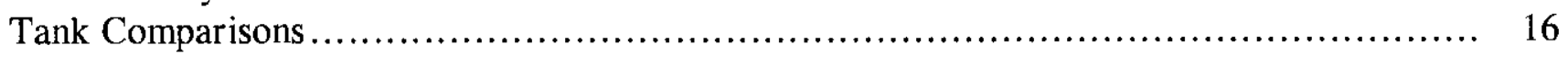

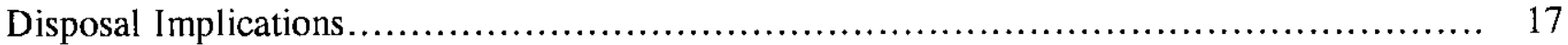

Scientists Assessment of Data Quality and Quantity ...................................... 18

Hydroxide Analyses................................................................... 20

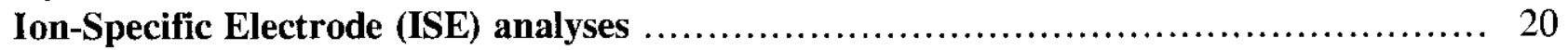

Spectrophotometric Analysis for Cyanide ........................................... 20

Cold Vapor AA for Mercury ...................................................... 20

Total Inorganic Carbon/Total Organic Carbon (TIC/TOC) Analyses .................... 22

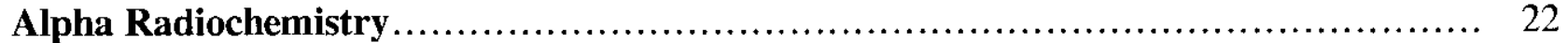

Unique Aspects of the Tank ............................................................. 24

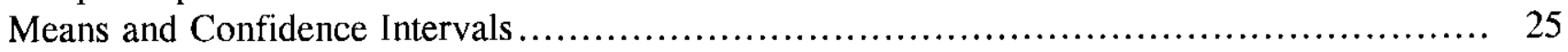

Best-Basis Inventory Derivation ....................................................... 26

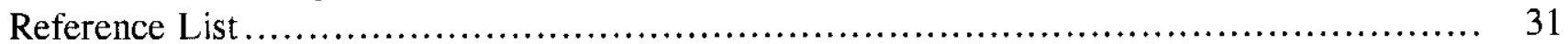




\section{RPP-SD-WM-ER-411, Rev. 1}

\section{Data Dictionary to Reports in this Document}

$\begin{array}{ll}\text { Report } & \text { Description } \\ \text { Tank Interpretive Report } & \text { Interprets information about the tank answering } \\ & \text { a series of seven questions covering areas such } \\ & \text { as information drivers, tank history, tank } \\ & \text { comparisons, disposal implications, data quality } \\ & \text { and quantity, and unique aspects of the tank. }\end{array}$




\section{RPP-SD-WM-ER-411, Rev. 1}

\section{Tank Interpretive Report For 241-AZ-102}

\section{Tank Information Drivers}

Question 1: What are the information drivers applicable to this tank? What type of information does each driver require from this tank? (Examples of drivers are Data Quality Objectives, Mid-Level Disposal Logic, RPP Operation and Utilization Plan, test plans and Letters of Instruction.) To what extent have the information and data required in the driving document been satisfied to date by the analytical and interpretive work done on this tank?

The information drivers for tank 241-AZ-102 include the Low Activity Waste and High Level Waste Feed Processing Data Quality Objectives (Low/High DQO), the Data Quality Objectives for RPP Privatization Phase 1: Confirm Tank T is an Appropriate Feed Source for High-Level Waste Feed Batch X (HLW DQO), the Data Quality Objectives for TWRS Privatization Phase 1: Confirm Tank $\mathrm{T}$ is an Appropriate Feed Source for Low-Activity Waste Feed Batch X (LAW DQO), Characterization Data Needs for Development, Design, and Operation of Retrieval Equipment Developed through the Data Quality Objective Process (Equipment DQO) Safety Screening DQO, Flammable Gas DQO, Air Emissions DQO, Dangerous Waste DQO, Additional Americium-241 analysis, and the Interface Control Document-23 (ICD-23) issue. The Equipment DQO is applied for shear strength measurements of the solids segments only. The AY/AZ ventilation system exhauster duct was sampled in support of the Air Emmisions DQO. Analytical results were not available as of the tank interpretive report (TIR) publication date. The issue of the Dangerous waste DQO is currently being evaluated and will be applied as necessary. The remaining issues are discussed below.

LAW and HLW Feed Processing DQO: Do the samples taken from tank 241-AZ-102 and the subsequent laboratory analysis meet the needs of the Low-Activity Waste and High-Level Waste Feed Processing Data Quality Objectives (Low/High DQO) (Patello et al. 1999)?

Solubility screening, a requirement of the Low/High DQO (Patello et al. 1999), has not been performed on the core samples at the time this report was prepared. A test plan has been written (Person 1999), and these solubility screening tests are planned for the near future.

Patello et al. (1999) requires that Group One (data needs for feed certification that are stated in the Privatization Contract Specification 7 (LAW) and 8 (HLW)) analytes from tank 241-AZ-102 liquids be compared against the Envelope B Limits stated in that DQO (Patello et al. 1999). The mean analytical values from the core 262 and core 268 liquid composites (see Means and Variances Standard Report) were used in the assessment. This comparison, which is shown in Table 1-1, demonstrates that the non-radionuclide Group One analytes met the Envelope B limits, with the exception of sulfate (110\%) sodium ratios. TRU $(153 \%),{ }^{60} \mathrm{Co}(516 \%)$, and ${ }^{154+155} \mathrm{Eu}(1165 \%)$ sodium ratios did exceed the Envelope B limit, but the measurements reported for these radionuclides are the upper bounding estimates from the detection limits for the analytes. If better detection limits are achieved for these analytes in the future, it may be shown that they are within the envelope limits. ${ }^{154} \mathrm{Eu}$ has a much better detection limit than ${ }^{155} \mathrm{Eu}$. In the 1999 composite solids, where the europium isotope concentrations were above the detection limit, the ${ }^{154} \mathrm{Eu}$ to ${ }^{155} \mathrm{Eu}$ ratio 
RPP-SD-WM-ER-411, Rev. 1

was 0.512 . If we assume the same isotopic ratio in the liquid and apply this ratio to the ${ }^{154} \mathrm{Eu}$ detection limit, the ${ }^{154+155} \mathrm{Eu}$ maximum mean is $.213 \mu \mathrm{Ci} / \mathrm{L}$, which comes to $250 \%$ of the envelope limits. Both europium isotopes have short half-lives, so the europium concentration would be expected to meet the envelope limits by the time the tank is retrieved for feed.

Table 1-1. Comparison of Tank 241-AZ-102 Liquids to Envelope B Limits

\begin{tabular}{|c|c|c|c|c|c|}
\hline Arinivis & $\begin{array}{l}\text { Mear } \\
\text { (19/nI? }\end{array}$ & Medr: & 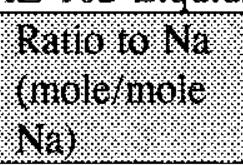 & $\begin{array}{l}\text { Invelope B } \\
\text { inits: }\end{array}$ & 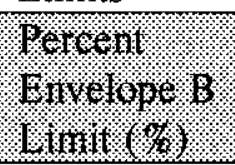 \\
\hline $\mathrm{Al}$ & $5.44 \mathrm{E}+02$ & $2.01 \mathrm{E}-02$ & $7.66 \mathrm{E}-03$ & $2.50 \mathrm{E}-01$ & 3.06 \\
\hline $\mathrm{Ba}$ & $5.09 \mathrm{E}-02$ & $3.71 \mathrm{E}-07$ & $1.41 \mathrm{E}-07$ & $1.00 \mathrm{E}-04$ & 0.14 \\
\hline $\mathrm{Ca}$ & $2.01 \mathrm{E}+01^{2}$ & $5.01 \mathrm{E}-04$ & $1.91 \mathrm{E}-04$ & $4.00 \mathrm{E}-02$ & 0.48 \\
\hline $\mathrm{Cd}$ & $1.01 \mathrm{E}+00^{2}$ & $8.98 \mathrm{E}-06$ & $3.42 \mathrm{E}-06$ & $4.00 \mathrm{E}-03$ & 0.09 \\
\hline $\mathrm{Cl}$ & $1.36 \mathrm{E}+02$ & $3.83 \mathrm{E}-03$ & $1.45 \mathrm{E}-03$ & $8.90 \mathrm{E}-02$ & 1.63 \\
\hline $\mathrm{Cr}$ & $8.04 \mathrm{E}+02$ & $1.55 \mathrm{E}-02$ & $5.88 \mathrm{E}-03$ & $2.00 \mathrm{E}-02$ & 29.39 \\
\hline $\mathrm{F}$ & $1.12 \mathrm{E}+03$ & $5.90 \mathrm{E}-02$ & $2.24 \mathrm{E}-02$ & $2.00 \mathrm{E}-01$ & 11.21 \\
\hline $\mathrm{Fe}$ & $1.01 \mathrm{E}+01^{2}$ & $1.81 \mathrm{E}-04$ & $6.87 \mathrm{E}-05$ & $1.00 \mathrm{E}-02$ & 0.69 \\
\hline $\mathrm{Hg}$ & $6.60 \mathrm{E}-02$ & $3.29 \mathrm{E}-07$ & $1.25 \mathrm{E}-07$ & $1.40 \mathrm{E}-05$ & 0.89 \\
\hline $\mathrm{K}$ & $3.37 \mathrm{E}+03$ & $8.62 \mathrm{E}-02$ & $3.28 \mathrm{E}-02$ & $1.80 \mathrm{E}-01$ & 18.20 \\
\hline $\mathrm{La}$ & $6.18 \mathrm{E}-02^{2}$ & $4.45 \mathrm{E}-07$ & $1.69 \mathrm{E}-07$ & $8.30 \mathrm{E}-05$ & 0.20 \\
\hline $\mathrm{Na}$ & $6.05 \mathrm{E}+04$ & $2.63 \mathrm{E}+00$ & $1.00 \mathrm{E}+00$ & $\mathrm{~N} / \mathrm{A}^{3}$ & $\mathrm{~N} / \mathrm{A}^{2}$ \\
\hline $\mathrm{Ni}$ & $4.02 \mathrm{E}+00^{2}$ & $6.85 \mathrm{E}-05$ & $2.60 \mathrm{E}-05$ & $3.00 \mathrm{E}-03$ & 0.87 \\
\hline $\mathrm{NO}_{2}$ & $3.65 \mathrm{E}+04$ & $7.93 \mathrm{E}-01$ & $3.01 \mathrm{E}-01$ & $3.80 \mathrm{E}-01$ & 79.30 \\
\hline $\mathrm{NO}_{3}$ & $1.85 \mathrm{E}+04$ & $2.98 \mathrm{E}-01$ & $1.13 \mathrm{E}-01$ & $8.00 \mathrm{E}-01$ & 14.18 \\
\hline $\mathrm{Pb}$ & $2.01 \mathrm{E}+01^{2}$ & $9.70 \mathrm{E}-05$ & $3.69 \mathrm{E}-05$ & $6.80 \mathrm{E}-04$ & 5.42 \\
\hline $\mathrm{PO}_{4}$ & $4.55 \mathrm{E}+02^{2}$ & $4.79 \mathrm{E}-03$ & $1.82 \mathrm{E}-03$ & $1.30 \mathrm{E}-01$ & 1.40 \\
\hline $\mathrm{SO}_{4}$ & $1.95 \mathrm{E}+04$ & $2.03 \mathrm{E}-01$ & $7.73 \mathrm{E}-02$ & $7.00 \mathrm{E}-02$ & 110.47 \\
\hline TIC & $7.01 \mathrm{E}+03$ & $5.84 \mathrm{E}-01$ & $2.22 \mathrm{E}-01$ & $3.00 \mathrm{E}-01$ & 73.97 \\
\hline TOC & $1.13 E+03$ & $\mathrm{E}-02$ & $3.57 \mathrm{E}-02$ & $5.00 \mathrm{E}-01$ & 7.13 \\
\hline $\mathrm{U}$ & $1.01 \mathrm{E}+02^{2}$ & $4.24 \mathrm{E}-04$ & $1.61 \mathrm{E}-04$ & $1.20 \mathrm{E}-03$ & 13.44 \\
\hline 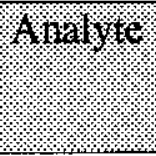 & $\begin{array}{l}\text { Mear } \\
\text { (MCinil: }\end{array}$ & 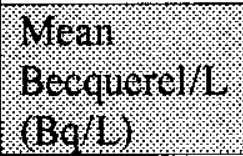 & $\begin{array}{l}\text { Ba analyeel } \\
\text { Morle Na: }\end{array}$ & $\begin{array}{l}\text { Envelope } \mathrm{P} \\
\text { l. mints }\end{array}$ & 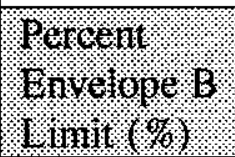 \\
\hline TRU & $5.23 \mathrm{E}-02^{2}$ & $1.94 \mathrm{E}+06$ & $7.36 \mathrm{E}+05$ & $4.80 \mathrm{E}+05$ & 153.35 \\
\hline${ }^{137} \mathrm{Cs}$ & $1.14 \mathrm{E}+03$ & $4.21 \mathrm{E}+10$ & $1.60 \mathrm{E}+10$ & $2.00 \mathrm{E}+10$ & 80.05 \\
\hline${ }^{90} \mathrm{Sr}$ & $2.34 \mathrm{E}+00$ & $8.66 \mathrm{E}+07$ & $3.29 \mathrm{E}+07$ & $4.40 \mathrm{E}+07$ & 74.85 \\
\hline${ }^{99} \mathrm{Tc}$ & $2.27 \mathrm{E}-01$ & $8.39 \mathrm{E}+06$ & $3.19 \mathrm{E}+06$ & $7.10 \mathrm{E}+06$ & 44.90 \\
\hline${ }^{60} \mathrm{Co}$ & $2.24 \mathrm{E}-02^{2}$ & $8.28 \mathrm{E}+05$ & $3.15 \mathrm{E}+05$ & $6.10 \mathrm{E}+04$ & 515.92 \\
\hline${ }^{154+155} \mathrm{Eu}$ & $9.94 \mathrm{E}-01^{2}$ & $3.68 \mathrm{E}+07$ & $1.40 \mathrm{E}+07$ & $1.20 \mathrm{E}+06$ & 1165.43 \\
\hline
\end{tabular}

Notes:

${ }^{1}$ Liquid core composite mean data.

${ }^{2}$ Maximum value, based on a detection limit.

${ }^{3}$ No envelope limit on $\mathrm{Na}$.

Patello et al. (1999) also requires that the tank solids be compared against the Envelope D limits. The weight percent oxide of the centrifuged solids measurements to be used in the Envelope D 


\section{RPP-SD-WM-ER-411, Rev. 1}

comparison were not performed because of sample quantity limitations. This measurement will be performed in conjunction with future solubility screening tests for the tank (Person 1999). The HLW Feed Source DQO (Nguyen 1999b), allows for the weight percent oxides to be determined by summing the mass of the oxide forming components. The results from that method are expected to be similar to results obtained by the method required by Patello et al. (1999). The weight percent oxide value determined for core 262 using the sum of the mass of the oxide forming components was 28.2 , and for core 268 was 29.6. Tables 1-2 through 1-7 show the sample results for the sludge in cores 262 and 268 in comparison to the Envelope D limits, using these determined weight percent oxide values.

Table 1-2. Non-Volatile Elements From Core 262 in Comparison to Envelope D Limits

\begin{tabular}{|c|c|c|c|}
\hline 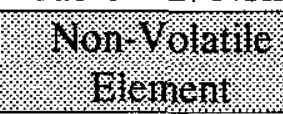 & 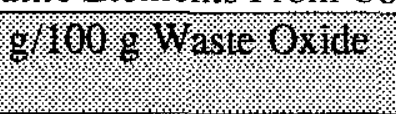 & 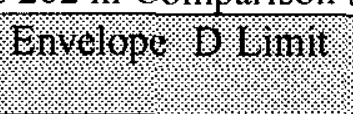 & 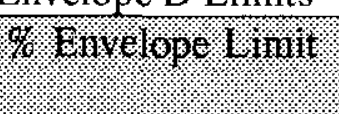 \\
\hline As & $6.06 \mathrm{E}-03$ & 0.16 & 3.79 \\
\hline $\mathrm{B}$ & $4.62 \mathrm{E}-01$ & 1.3 & 35.54 \\
\hline $\mathrm{Be}$ & $1.32 \mathrm{E}-03$ & 0.065 & 2.03 \\
\hline $\mathrm{Ce}$ & $9.36 \mathrm{E}-02$ & 0.81 & 11.56 \\
\hline Co & $6.97 \mathrm{E}-03$ & 0.45 & 1.55 \\
\hline $\mathrm{Cs}^{2}$ & $3.22 \mathrm{E}-02$ & 0.58 & 5.55 \\
\hline $\mathrm{Cu}$ & $2.41 \mathrm{E}-02$ & $0 . \overline{48}$ & 5.03 \\
\hline $\mathrm{Hg}$ & $6.47 \mathrm{E}-04$ & 0.1 & 0.65 \\
\hline $\mathrm{La}$ & $4.50 \mathrm{E}-01$ & 2.6 & 17.33 \\
\hline $\mathrm{Li}$ & $1.21 \mathrm{E}-03^{1}$ & 0.14 & 0.86 \\
\hline $\mathrm{Mn}$ & $3.70 \mathrm{E}-01$ & 6.5 & 5.69 \\
\hline Mo & $1.31 \mathrm{E}-02$ & 0.65 & 2.01 \\
\hline $\mathrm{Nd}$ & $2.97 \mathrm{E}-01$ & 1.7 & 17.48 \\
\hline $\mathrm{Pr}$ & $6.06 \mathrm{E}-02$ & 0.35 & 17.31 \\
\hline $\mathrm{Pu}^{3}$ & $1.32 \mathrm{E}-02$ & 0.054 & 24.51 \\
\hline $\mathrm{Rb}$ & $9.11 \mathrm{E}-04$ & 0.19 & 0.48 \\
\hline Sb & $9.45 \mathrm{E}-04$ & 0.84 & 0.11 \\
\hline $\mathrm{Se}$ & $1.77 \mathrm{E}-03^{1}$ & 0.52 & 0.34 \\
\hline $\mathrm{Sr}$ & $3.47 \mathrm{E}-02$ & 0.52 & 6.67 \\
\hline $\mathrm{Ta}$ & $4.83 \mathrm{E}-04^{1}$ & 0.03 & 1.61 \\
\hline $\mathrm{Tc}$ & $3.26 \mathrm{E}-03$ & 0.26 & 1.25 \\
\hline $\mathrm{Te}$ & $1.07 \mathrm{E}-02$ & 0.13 & 8.23 \\
\hline Th & $5.71 \mathrm{E}-02$ & 0.52 & 10.98 \\
\hline $\mathrm{Tl}$ & $4.83 \mathrm{E}-04^{1}$ & 0.45 & 0.11 \\
\hline $\mathrm{V}$ & $6.05 \mathrm{E}-03^{1}$ & 0.032 & 18.92 \\
\hline W & $3.89 \mathrm{E}-03$ & 0.24 & 1.62 \\
\hline Y & $2.31 \mathrm{E}-02$ & 0.26 & 8.89 \\
\hline $\mathrm{Zn}$ & $1.72 \mathrm{E}-02$ & 0.42 & 4.10 \\
\hline
\end{tabular}

Notes:

${ }^{1}$ Maximum value, based on a detection limit

${ }^{2}$ Based on the sum of isotopes 133,135 , and 137

${ }^{3}$ Based on the sum of isotopes $239,240,241$, and 242 
RPP-SD-WM-ER-411, Rev. 1

Table 1-3. Volatile Components From Core 262 in Comparison to Envelope D Limits

\begin{tabular}{|c|c|c|c|}
\hline 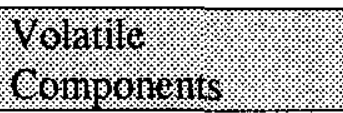 & 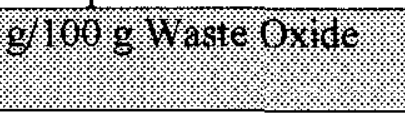 & 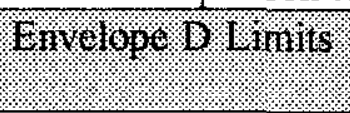 & 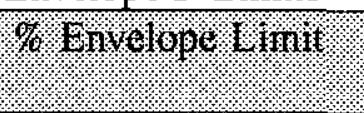 \\
\hline $\mathrm{Cl}$ & $8.70 \mathrm{E}-02^{1}$ & 0.33 & 26.36 \\
\hline $\mathrm{CO}_{3}$ & $1.19 \mathrm{E}+01$ & 30 & 39.59 \\
\hline $\mathrm{NO}_{2}+\mathrm{NO}_{3}$ as $\mathrm{NO}_{3}$ & $1.45 \mathrm{E}+01$ & 36 & 40.35 \\
\hline TOC & $6.46 \mathrm{E}-01$ & 11 & 5.87 \\
\hline Cyanide & $4.58 \mathrm{E}-03$ & 1.6 & 0.29 \\
\hline $\mathrm{NH}_{3}$ & $9.77 \mathrm{E}-01$ & 1.6 & 61.07 \\
\hline
\end{tabular}

Notes:

${ }^{1}$ Maximum value, based on a detection limit

Table 1-4. Radionuclides From Core 262 in Comparison to Envelope D Limits

\begin{tabular}{|c|c|c|c|}
\hline 1801938. & 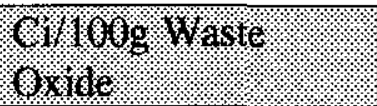 & RHY & 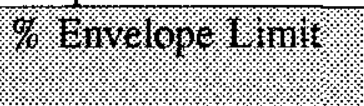 \\
\hline${ }^{3} \mathrm{H}$ & $7.85 \mathrm{E}-06$ & $6.50 \mathrm{E}-05$ & 12.07 \\
\hline${ }^{14} \mathrm{C}$ & $3.68 \mathrm{E}-07$ & $6.50 \mathrm{E}-06$ & 5.66 \\
\hline${ }^{60} \mathrm{Co}$ & $5.07 \mathrm{E}-04$ & $1.00 \mathrm{E}-02$ & 5.07 \\
\hline${ }^{90} \mathrm{Sr}$ & $1.83 E+00$ & $1.00 \mathrm{E}+01$ & 18.28 \\
\hline${ }^{99} \mathrm{Tc}$ & $5.18 \mathrm{E}-05$ & $1.50 \mathrm{E}-02$ & 0.35 \\
\hline${ }^{125} \mathrm{Sb}$ & $3.31 \mathrm{E}-03$ & $3.20 \mathrm{E}-02$ & 10.36 \\
\hline${ }^{126} \mathrm{Sn}$ & $6.85 \mathrm{E}-05^{1}$ & $1.50 \mathrm{E}-04$ & 45.69 \\
\hline${ }^{129} \mathrm{I}$ & $1.24 \mathrm{E}-06^{1}$ & $2.90 \mathrm{E}-07$ & 426.05 \\
\hline${ }^{137} \mathrm{Cs}$ & $2.98 \mathrm{E}-01$ & $1.00 \mathrm{E}+00$ & 29.75 \\
\hline${ }^{152} \mathrm{Eu}$ & $7.45 \mathrm{E}-04^{1}$ & $4.80 \mathrm{E}-04$ & 155.20 \\
\hline${ }^{154} \mathrm{Eu}$ & $4.67 \mathrm{E}-03$ & $5.20 \mathrm{E}-02$ & 8.98 \\
\hline${ }^{155} \mathrm{Eu}$ & $8.81 \mathrm{E}-03$ & $2.90 \mathrm{E}-02$ & 30.36 \\
\hline${ }^{233} \mathrm{U}$ & $1.87 \mathrm{E}-06^{1}$ & $9.00 \mathrm{E}-07$ & 207.66 \\
\hline${ }^{235} \mathrm{U}$ & $5.06 \mathrm{E}-08$ & $2.50 \mathrm{E}-07$ & 20.24 \\
\hline${ }^{237} \mathrm{~Np}$ & $9.64 \mathrm{E}-06$ & $7.40 \mathrm{E}-05$ & 13.03 \\
\hline${ }^{238} \mathrm{Pu}$ & $0.00 \mathrm{E}+00$ & $3.50 \mathrm{E}-04$ & 0.00 \\
\hline${ }^{239} \mathrm{Pu}$ & $7.23 \mathrm{E}-04$ & $3.10 \mathrm{E}-03$ & 23.33 \\
\hline${ }^{241} \mathrm{Pu}^{2}$ & $1.27 \mathrm{E}-04$ & $2.20 \mathrm{E}-02$ & 0.58 \\
\hline${ }^{241} \mathrm{Am}$ & $9.71 \mathrm{E}-03$ & $9.00 \mathrm{E}-02$ & 10.79 \\
\hline${ }^{243 / 244} \mathrm{Cm}$ & $0.00 \mathrm{E}+00$ & $3.00 \mathrm{E}-03$ & 0.00 \\
\hline
\end{tabular}

Notes:

'Maximum value, based on a detection limit.

${ }^{2}$ Based on atomic mass unit 241 , and subtracting out the americium-241 contribution. 


\section{RPP-SD-WM-ER-411, Rev. 1}

Table 1-5. Non-Volatile Elements From Core 268 in Comparison to Envelope D Limits

\begin{tabular}{|c|c|c|c|}
\hline 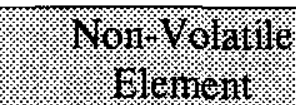 & 91910.9. Waste & Ervelope I Limi & Of Invelope I Init \\
\hline As & $5.95 \mathrm{E}-03$ & 0.16 & 3.72 \\
\hline $\mathrm{B}$ & $3.93 \mathrm{E}-01$ & 1.3 & 30.27 \\
\hline $\mathrm{Be}$ & $1.51 \mathrm{E}-03$ & 0.065 & 2.32 \\
\hline $\mathrm{Ce}$ & $1.09 \mathrm{E}-01$ & 0.81 & 13.51 \\
\hline Co & $9.32 \mathrm{E}-03$ & 0.45 & 2.07 \\
\hline $\mathrm{Cs}^{2}$ & $9.32 \mathrm{E}-03$ & 0.58 & 1.61 \\
\hline $\mathrm{Cu}$ & $3.04 \mathrm{E}-02$ & 0.48 & 6.33 \\
\hline $\mathrm{Hg}$ & $4.08 \mathrm{E}-03$ & 0.1 & 4.08 \\
\hline $\mathrm{La}$ & $6.99 \mathrm{E}-01$ & 2.6 & 26.88 \\
\hline $\mathrm{Li}$ & $1.16 \mathrm{E}-03^{1}$ & 0.14 & 0.83 \\
\hline $\mathrm{Mn}$ & $3.99 \mathrm{E}-01$ & 6.5 & 6.14 \\
\hline Mo & $1.05 \mathrm{E}-02$ & 0.65 & 1.61 \\
\hline $\mathrm{Nd}$ & $4.08 \mathrm{E}-01$ & 1.7 & 23.98 \\
\hline $\mathrm{Pr}$ & $7.29 \mathrm{E}-02$ & 0.35 & 20.83 \\
\hline $\mathrm{Pu}^{3}$ & $1.25 \mathrm{E}-02$ & 0.054 & 23.16 \\
\hline $\mathrm{Rb}$ & $7.32 \mathrm{E}-04$ & 0.19 & 0.39 \\
\hline $\mathrm{Sb}$ & $7.59 \mathrm{E}-04$ & 0.84 & 0.09 \\
\hline $\mathrm{Se}$ & $1.54 \mathrm{E}-03^{1}$ & 0.52 & 0.30 \\
\hline $\mathrm{Sr}$ & $3.42 \mathrm{E}-02$ & 0.52 & 6.57 \\
\hline $\mathrm{Ta}$ & $4.61 \mathrm{E}-04^{1}$ & 0.03 & 1.54 \\
\hline $\mathrm{Tc}$ & $3.02 \mathrm{E}-03$ & 0.26 & 1.16 \\
\hline $\mathrm{Te}$ & $1.14 \mathrm{E}-02$ & 0.13 & 8.80 \\
\hline Th & $4.29 \mathrm{E}-02$ & 0.52 & 8.24 \\
\hline $\mathrm{Tl}$ & $4.61 \mathrm{E}-04^{1}$ & 0.45 & 0.10 \\
\hline $\mathrm{V}$ & $5.81 \mathrm{E}-03^{1}$ & 0.032 & 18.17 \\
\hline W & $2.51 \mathrm{E}-03$ & 0.24 & 1.05 \\
\hline Y & $2.40 \mathrm{E}-02$ & 0.26 & 9.23 \\
\hline $\mathrm{Zn}$ & $1.79 \mathrm{E}-02$ & 0.42 & 4.27 \\
\hline
\end{tabular}

Notes:

${ }^{1}$ Maximum value, based on a detection limit

${ }^{2}$ Based on the sum of isotopes 133, 135, and 137

${ }^{3}$ Based on the sum of isotopes $239,240,241$, and 242 


\section{RPP-SD-WM-ER-411, Rev. 1}

Table 1-6. Volatile Components From Core 268 in Comparison to Envelope D Limits

\begin{tabular}{|c|c|c|c|}
\hline (\%) & 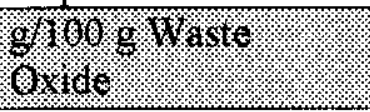 & 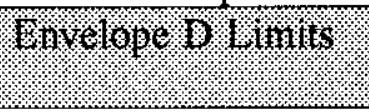 & 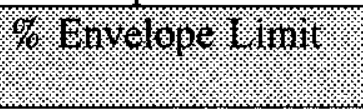 \\
\hline $\mathrm{Cl}$ & $8.10 \mathrm{E}-02^{1}$ & 0.33 & 24.56 \\
\hline $\mathrm{CO}_{3}$ & $1.20 \mathrm{E}+01$ & 30 & 39.90 \\
\hline $\mathrm{NO}_{2}+\mathrm{NO}_{3}$ as $\mathrm{NO}_{3}$ & $1.40 \mathrm{E}+01$ & 36 & 38.81 \\
\hline TOC & $6.45 \mathrm{E}-01$ & 11 & 5.87 \\
\hline Cyanide & $2.76 \mathrm{E}-03$ & 1.6 & 0.17 \\
\hline $\mathrm{NH}_{3}$ & $1.11 \mathrm{E}+00^{1}$ & 1.6 & 69.13 \\
\hline
\end{tabular}

Notes:

${ }^{1}$ Maximum value, based on a detection limit

Table 1-7. Radionuclides From Core 268 in Comparison to Envelope D Limits

\begin{tabular}{|c|c|c|c|}
\hline 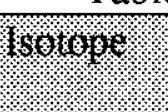 & \%.ricle: : & 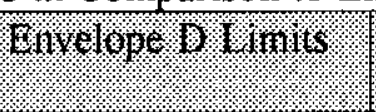 & 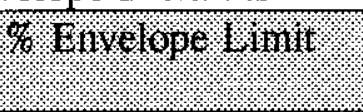 \\
\hline${ }^{3} \mathrm{H}$ & $6.52 \mathrm{E}-06$ & $6.50 \mathrm{E}-05$ & 10.02 \\
\hline${ }^{14} \mathrm{C}$ & $2.25 \mathrm{E}-07$ & $6.50 \mathrm{E}-06$ & 3.47 \\
\hline${ }^{60} \mathrm{Co}$ & $7.18 \mathrm{E}-04$ & $1.00 \mathrm{E}-02$ & 7.18 \\
\hline${ }^{90} \mathrm{Sr}$ & $2.53 \mathrm{E}+00$ & $1.00 \mathrm{E}+01$ & 25.27 \\
\hline${ }^{99} \mathrm{Tc}$ & $5.13 \mathrm{E}-05$ & $1.50 \mathrm{E}-02$ & 0.34 \\
\hline${ }^{125} \mathrm{Sb}$ & $4.93 \mathrm{E}-03$ & $3.20 \mathrm{E}-02$ & 15.40 \\
\hline${ }^{126} \mathrm{Sn}$ & $6.55 \mathrm{E}-05^{1}$ & $1.50 \mathrm{E}-04$ & 43.64 \\
\hline${ }^{129} \mathrm{I}$ & $1.70 \mathrm{E}-06^{1}$ & $2.90 \mathrm{E}-07$ & 586.70 \\
\hline${ }^{137} \mathrm{Cs}$ & $3.10 \mathrm{E}-01$ & $1.00 \mathrm{E}+00$ & 31.00 \\
\hline${ }^{152} \mathrm{Eu}$ & $1.14 \mathrm{E}-03^{1}$ & $4.80 \mathrm{E}-04$ & 238.23 \\
\hline${ }^{154} \mathrm{Eu}$ & $6.43 \mathrm{E}-03$ & $5.20 \mathrm{E}-02$ & 12.37 \\
\hline${ }^{155} \mathrm{Eu}$ & $1.18 \mathrm{E}-02$ & $2.90 \mathrm{E}-02$ & 40.54 \\
\hline${ }^{233} \mathrm{U}$ & $1.78 \mathrm{E}-06^{1}$ & $9.00 \mathrm{E}-07$ & 198.33 \\
\hline${ }^{235} \mathrm{U}$ & $5.10 \mathrm{E}-08$ & $2.50 \mathrm{E}-07$ & 20.39 \\
\hline${ }^{237} \mathrm{~Np}$ & $9.16 \mathrm{E}-06$ & $7.40 \mathrm{E}-05$ & 12.37 \\
\hline${ }^{238} \mathrm{Pu}$ & $0.00 \mathrm{E}+00$ & $3.50 \mathrm{E}-04$ & 0.00 \\
\hline${ }^{239} \mathrm{Pu}$ & $6.82 \mathrm{E}-04$ & $3.10 \mathrm{E}-03$ & 21.99 \\
\hline${ }^{241} \mathrm{Pu}^{2}$ & $2.49 \mathrm{E}-05$ & $2.20 \mathrm{E}-02$ & 0.11 \\
\hline${ }^{241} \mathrm{Am}$ & $1.59 \mathrm{E}-02$ & $9.00 \mathrm{E}-02$ & 17.66 \\
\hline${ }^{243 / 244} \mathrm{Cm}$ & $0.00 \mathrm{E}+00$ & $3.00 \mathrm{E}-03$ & 0.00 \\
\hline
\end{tabular}

Notes:

${ }^{1}$ Maximum value, based on a detection limit.

${ }^{2}$ Based on atomic mass unit 241 , and subtracting out the americium-241 contribution.

The Low/High DQO (Patello et al. 1999) states that the Group Two analytes be measured, but gives no decision requirement relating to the concentration. These results are reported in the Analytical Results standard report. 
RPP-SD-WM-ER-411, Rev. 1

Patello et al. (1999) has a \% relative standard deviation (RSD) requirement of $3.5 \%$ for sodium and $15 \%$ for all other analytes. These limits are applicable to both LAW and HLW. The \% RSD calculation included three subsample analytical values from the liquid and solid phases of each core composite (core 262 and core 268) following centrifugation of the composite. All of the analytes that failed the \% RSD requirement are shown in Table 1-8. This statistic (\% RSD) is not defined for analytical values listed as the upper bounding estimate from the detection limit for the analyte.

Table 1-8. Analytes that Failed the $\% \mathrm{RSD}(2$ pages)

\begin{tabular}{|c|c|c|c|}
\hline 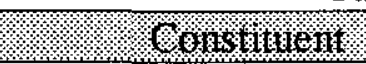 & /. & 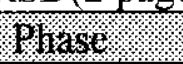 & \%. W 1 \\
\hline Aluminum & ICP-Acid Digest & $\begin{array}{l}\text { Liquid, } \\
\text { Core } 268\end{array}$ & 51.38 \\
\hline Americium-241 & TRU-Spec Resin & $\begin{array}{l}\text { Solid, } \\
\text { Core } 262\end{array}$ & 17.84 \\
\hline Ammonia & $\begin{array}{l}\text { Ion Selective Electrode } \\
\left(\mathrm{NH}_{3}\right)\end{array}$ & $\begin{array}{l}\text { Solid, } \\
\text { Core } 262\end{array}$ & 70.70 \\
\hline Ammonia $^{1}$ & $\begin{array}{l}\text { Ion Selective Electrode } \\
\text { (NH3) }\end{array}$ & $\begin{array}{l}\text { Liquid, } \\
\text { Core } 262\end{array}$ & 124.91 \\
\hline Boron & ICP-Acid Digest & $\begin{array}{l}\text { Solid, } \\
\text { Core } 262\end{array}$ & 24.98 \\
\hline Boron & ICP-Acid Digest & $\begin{array}{l}\text { Solid, } \\
\text { Core } 268\end{array}$ & 28.17 \\
\hline Chloride & IC & $\begin{array}{l}\text { Solid, } \\
\text { Core } 262\end{array}$ & 55.90 \\
\hline Chloride & IC & $\begin{array}{l}\text { Liquid, } \\
\text { Core } 268\end{array}$ & 52.69 \\
\hline Cobalt- 60 & GEA & $\begin{array}{l}\text { Solid, } \\
\text { Core } 262\end{array}$ & 15.90 \\
\hline Cyanide & Water Distillation & $\begin{array}{l}\text { Solid, } \\
\text { Core } 262\end{array}$ & 60.87 \\
\hline Hydroxide $^{1}$ & Pot. Titration & $\begin{array}{l}\text { Liquid, } \\
\text { Core } 262\end{array}$ & 17.56 \\
\hline Hydroxide $^{1}$ & Pot. Titration & $\begin{array}{l}\text { Liquid, } \\
\text { Core } 268\end{array}$ & 38.44 \\
\hline Lead $^{1}$ & ICP-Acid Digest & $\begin{array}{l}\text { Solid, } \\
\text { Core } 262\end{array}$ & 23.52 \\
\hline Mercury & CVAA $(\mathrm{Hg})$ & $\begin{array}{l}\text { Liquid, } \\
\text { Core } 262\end{array}$ & 16.78 \\
\hline Mercury & CVAA $(\mathrm{Hg})$ & $\begin{array}{l}\text { Solid, } \\
\text { Core } 268\end{array}$ & 18.21 \\
\hline Neptunium-237 & ICP/MS & $\begin{array}{l}\text { Liquid, } \\
\text { Core } 268\end{array}$ & 22.92 \\
\hline Phosphorus $^{1}$ & ICP-Acid Digest & $\begin{array}{l}\text { Solid, } \\
\text { Core } 262\end{array}$ & 90.80 \\
\hline Phosphorus $^{1}$ & ICP-Acid Digest & $\begin{array}{l}\text { Solid, } \\
\text { Core } 268\end{array}$ & 122.74 \\
\hline Plutonium-239 & ICP/MS & $\begin{array}{l}\text { Liquid, } \\
\text { Core } 268\end{array}$ & 23.00 \\
\hline
\end{tabular}


RPP-SD-WM-ER-411, Rev. 1

Table 1-8. Analytes that Failed the $\%$ RSD(2 pages)

\begin{tabular}{|c|c|c|c|}
\hline 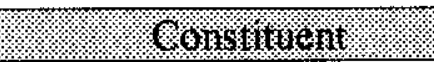 & Nethod & Pliase: & $98 \mathrm{RSO}$ \\
\hline Silicon $^{1}$ & ICP-Acid Digest & $\begin{array}{l}\text { Liquid, } \\
\text { Core } 262 \\
\end{array}$ & 70.93 \\
\hline Silicon' & ICP-Acid Digest & $\begin{array}{l}\text { Solid, } \\
\text { Core } 262\end{array}$ & 36.35 \\
\hline Sodium & ICP-Acid Digest & $\begin{array}{l}\text { Solid, } \\
\text { Core } 262 \\
\end{array}$ & 8.36 \\
\hline Sodium & ICP-Acid Digest & $\begin{array}{l}\text { Liquid, } \\
\text { Core } 268 \\
\end{array}$ & 6.42 \\
\hline Sodium & ICP-Acid Digest & $\begin{array}{l}\text { Solid, } \\
\text { Core } 268\end{array}$ & 5.91 \\
\hline Total Inorganic Carbon ${ }^{1}$ & Acid/Coulometry & $\begin{array}{l}\text { Solid, } \\
\text { Core } 268\end{array}$ & 21.35 \\
\hline Total Alpha & Alpha Radiochemistry & $\begin{array}{l}\text { Liquid, } \\
\text { Core } 268\end{array}$ & 16.10 \\
\hline Total Organic Carbon & Persulfate Oxidation & $\begin{array}{l}\text { Solid, } \\
\text { Core } 262\end{array}$ & 22.21 \\
\hline Total Organic Carbon & Persulfate Oxidation & $\begin{array}{l}\text { Solid, } \\
\text { Core } 268\end{array}$ & 32.48 \\
\hline Uranium-235 & ICP/MS-Acid Digest & $\begin{array}{l}\text { Liquid, } \\
\text { Core } 268\end{array}$ & 23.16 \\
\hline Uranium-236 & ICP/MS-Acid Digest & $\begin{array}{l}\text { Liquid, } \\
\text { Core } 268\end{array}$ & 29.54 \\
\hline Uranium-238 & ICP/MS-Acid Digest & $\begin{array}{l}\text { Liquid, } \\
\text { Core } 268\end{array}$ & 22.76 \\
\hline
\end{tabular}

Notes:

${ }^{1}$ Relative standard deviation exceeds Tables 7.1 and 7.2 (Patello et al. 1999) acceptance criteria but reanalysis is not required because analyte is not included in the envelope limit.

LAW, Waste Feed Delivery DQO: Does the liquid waste meet specifications as a LAW feed source for waste treatment?

The current data required to support waste feed delivery for Phase I low-activity waste are documented in Data Quality Objectives for TWRS Privatization Phase I: Confirm Tank T is an Appropriate Feed Source for Low-Activity Waste Feed Batch X (LAW Feed Source DQO) (Nguyen 1999a).

This DQO (Nguyen1999a) requires comparison of the 1999 core samples to the Envelope B limits stated in the DQO. These are identical to the limits in the Patello et al. (1999) DQO above, and are presented in Table 1-1.

Nguyen (1999a) does not give a decision limit on the quantity of Envelope B waste this tank provides but does require that the quantity be reported. Nguyen (1999a) states that 1 metric ton of sodium 


\section{RPP-SD-WM-ER-411, Rev. 1}

$(\mathrm{Na})=2.6$ units for Envelope B waste. At the time the core samples were taken, the tank supernatant volume was $3,285 \mathrm{~kL}$ ( $868 \mathrm{kgal})$, and the sodium concentration was $55,900 \mu \mathrm{g} / \mathrm{ml}$. From these data, 184 metric tons of $\mathrm{Na}$ are calculated for the tank 241-AZ-102 supernatant, which translates into 477 units.

For tanks with less than $1 \mathrm{M}$ nitrate, the DQO states that hydroxide concentration must be between $0.010 \mathrm{M}$ and $5.0 \mathrm{M}$, the nitrite concentration must be between $0.011 \mathrm{M}$ and $5.5 \mathrm{M}$, and nitrate/(hydroxide + nitrite) must be less than 2.5. The supernatant in tank 241-AZ-102 has a nitrate concentration of $0.30 \mathrm{M}$, a hydroxide concentration of $0.05 \mathrm{M}$, a nitrite concentration of $0.80 \mathrm{M}$, and nitrate/(hydroxide + nitrite) $=0.35$. The concentrations for the tank meet specification limits.

The detection limits for some analytes did not meet the minimum reportable quantities (MRQs) required by the DQO (Nguyen 1999a). The high concentration of one or more analytes in multi-analyte methods such as IC and ICP required a greater dilution than expected for meeting the MRQs (Steen 2000a). In addition, the high radionuclide activity in the samples required reduced sample sizes or larger dilutions, which contributed to the higher detection limits reported for some of the methods.

HLW, Waste Feed Delivery DQO: Does the solid waste meet specifications as a HLW feed source for waste treatment?

The current data required to support waste feed delivery for Phase I low-activity waste are documented in Data Quality Objectives for RPP Privatization Phase I: Confirm Tank T is an Appropriate Feed Source for High-Level Waste Feed Batch X (HLW Feed Source DQO) (Nguyen 1999b). The DQO outlines three criteria for determining if the waste is appropriate for use as feed material. The criteria include assessing the feed characteristics, physical and rheological characteristics, and quantity properties of the tank waste.

The HLW Feed Source DQO (Nguyen 1999b) requires that the analytical results for the solids from two cores be averaged and compared against the Envelope D Requirements listed in the DQO. The Envelope D requirements are in the form of grams of constituent in the oxide form per 100 grams of oxide in the waste. The constituent concentrations from the core 262 and core 268 composite means (see Means and Variances Standard Report), in $\mu \mathrm{g} / \mathrm{g}$, were converted to grams of oxide using the stoichiometry presented in Nguyen (1999b). The weight percent oxide value determined using the sum of the mass of the oxide forming components was 28.5 .

The comparisons required by Nguyen (1999b) are shown below in Tables 1-9 through 1-11. All non-radionuclides were within the Envelope D limits, but ${ }^{129} \mathrm{I}(220.82 \%),{ }^{1.2} \mathrm{Eu}(200.42 \%)$, and ${ }^{233} \mathrm{U}(205.68 \%)$ exceeded the envelope limits. These values are upper bounding values based on detection limits, and if lower detection limits are achieved for these analytes in the future, it may be shown that they are within the envelope limits. The ${ }^{241} \mathrm{Pu}$ value was determined from the measurement of the atomic mass unit 241 by ICP/MS, where the mass of ${ }^{241} \mathrm{Am}$, determined by gamma energy analysis, was subtracted out. Thus, the variability associated with both the ${ }^{241} \mathrm{Am}$ and atomic mass unit 241 go into the ${ }^{241} \mathrm{Pu}$ value. 
RPP-SD-WM-ER-411, Rev. 1

Table 1-9. Non-Volatile Elements From Core 262 and Core 268 in Comparison to Envelope D Limits

\begin{tabular}{|c|c|c|c|}
\hline - Mon Molutile & 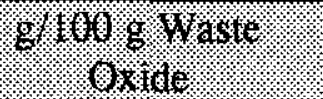 & Hiverope. I I IIIII & H. \\
\hline As & 6.07E-03 & 0.16 & 3.79 \\
\hline $\mathrm{B}$ & $4.36 \mathrm{E}-01$ & 1.3 & 33.54 \\
\hline $\mathrm{Be}$ & $1.44 \mathrm{E}-03$ & 0.065 & 2.21 \\
\hline $\mathrm{Ce}$ & $1.03 \mathrm{E}-01$ & 0.81 & 12.75 \\
\hline $\mathrm{Co}$ & $8.29 \mathrm{E}-03$ & 0.45 & 1.84 \\
\hline $\mathrm{Cs}^{2}$ & $3.35 \mathrm{E}-02$ & 0.58 & 5.78 \\
\hline $\mathrm{Cu}$ & $2.77 \mathrm{E}-02$ & 0.48 & 5.77 \\
\hline $\mathrm{Hg}$ & $2.44 \mathrm{E}-03$ & 0.1 & 2.44 \\
\hline $\mathrm{La}$ & $5.81 \mathrm{E}-01$ & 2.6 & 22.36 \\
\hline $\mathrm{Li}$ & $1.20 \mathrm{E}-03^{1}$ & 0.14 & 0.86 \\
\hline $\mathrm{Mn}$ & $3.70 \mathrm{E}-01$ & 6.5 & 5.69 \\
\hline Mo & $1.18 \mathrm{E}-02$ & 0.65 & 1.82 \\
\hline $\mathrm{Nd}$ & $3.58 \mathrm{E}-01$ & 1.7 & 21.09 \\
\hline $\mathrm{Pa}$ & $6.78 \mathrm{E}-02$ & 0.35 & 19.38 \\
\hline $\mathrm{Pu}^{3}$ & $1.30 \mathrm{E}-02$ & 0.054 & 24.14 \\
\hline $\mathrm{Rb}$ & $8.31 \mathrm{E}-04$ & 0.19 & 0.44 \\
\hline $\mathrm{Sb}$ & $8.62 \mathrm{E}-04$ & 0.84 & 0.10 \\
\hline $\mathrm{Se}$ & $1.67 \mathrm{E}-03^{1}$ & 0.52 & 0.32 \\
\hline $\mathrm{Sr}$ & $3.49 \mathrm{E}-02$ & 0.52 & 6.71 \\
\hline $\mathrm{Ta}$ & $4.78 \mathrm{E}-04^{1}$ & 0.03 & 1.59 \\
\hline $\mathrm{Tc}$ & $3.18 \mathrm{E}-03$ & 0.26 & 1.22 \\
\hline $\mathrm{Te}$ & $1.12 \mathrm{E}-02$ & 0.13 & 8.64 \\
\hline $\mathrm{Th}$ & $5.09 \mathrm{E}-02$ & 0.52 & 9.78 \\
\hline $\mathrm{Tl}$ & $4.78 \mathrm{E}-04^{1}$ & 0.45 & 0.11 \\
\hline $\mathrm{V}$ & $6.01 \mathrm{E}-03^{1}$ & 0.032 & 18.79 \\
\hline W & $3.23 \mathrm{E}-03$ & 0.24 & 1.35 \\
\hline$Y$ & $2.49 \mathrm{E}-02$ & 0.26 & 9.58 \\
\hline $\mathrm{Zn}$ & $1.78 \mathrm{E}-02$ & 0.42 & 4.25 \\
\hline
\end{tabular}

Notes:

${ }^{1}$ Maximum value, based on a detection limit

${ }^{2}$ Based on the sum of isotopes 133,135 , and 137

${ }^{3}$ Based on the sum of isotopes 239,240 , and 242 


\section{RPP-SD-WM-ER-411, Rev. 1}

Table 1-10. Volatile Components From Core 262 and Core 268 in Comparison to

Envelope D Limits

\begin{tabular}{|c|c|c|c|}
\hline 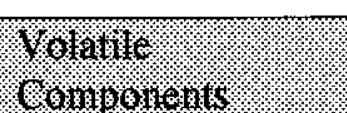 & 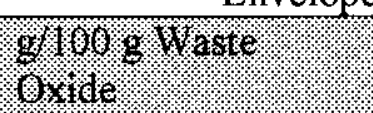 & 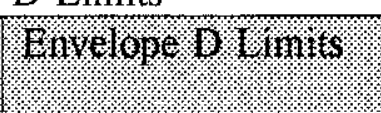 & 7. Envelope I inn \\
\hline $\mathrm{Cl}$ & $8.51 \mathrm{E}-02^{1}$ & 0.33 & 25.79 \\
\hline $\mathrm{CO}_{3}$ & $1.21 \mathrm{E}+01$ & 30 & 40.30 \\
\hline $\mathrm{NO}_{2}+\mathrm{NO}_{3}$ as $\mathrm{NO}_{3}$ & $1.44 \mathrm{E}+01$ & 36 & 40.11 \\
\hline TOC & $6.54 \mathrm{E}-01$ & 11 & 5.95 \\
\hline Cyanide & $3.70 \mathrm{E}-03$ & 1.6 & 0.23 \\
\hline $\mathrm{NH}_{3}$ & $1.06 \mathrm{E}+00^{1}$ & 1.6 & 66.09 \\
\hline
\end{tabular}

Notes:

${ }^{1}$ Maximum value, based on a detection limit

Table 1-11. Radionuclides From Core 262 and Core 268 in Comparison to Envelope D Limits

\begin{tabular}{|c|c|c|c|}
\hline tsologe & 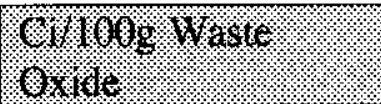 & Envelope D I intms & \% Envelope in mis \\
\hline${ }^{3} \mathrm{H}$ & $7.26 \mathrm{E}-06$ & $6.50 \mathrm{E}-05$ & 11.18 \\
\hline${ }^{14} \mathrm{C}$ & $2.99 \mathrm{E}-07$ & $6.50 \mathrm{E}-06$ & 4.60 \\
\hline${ }^{60} \mathrm{Co}$ & $6.23 \mathrm{E}-04$ & $1.00 \mathrm{E}-02$ & 6.23 \\
\hline${ }^{90} \mathrm{Sr}$ & $2.22 \mathrm{E}+00$ & $1.00 \mathrm{E}+01$ & 22.16 \\
\hline${ }^{99} \mathrm{Tc}$ & $5.40 \mathrm{E}-05$ & $1.50 \mathrm{E}-02$ & 0.36 \\
\hline${ }^{125} \mathrm{Sb}$ & $4.20 \mathrm{E}-03$ & $3.20 \mathrm{E}-02$ & 13.11 \\
\hline${ }^{126} \mathrm{Sn}$ & $6.79 \mathrm{E}-05^{1}$ & $1.50 \mathrm{E}-04$ & 45.26 \\
\hline${ }^{129} \mathrm{I}$ & 1.49E-06 ${ }^{1}$ & $2.90 \mathrm{E}-07$ & 515.28 \\
\hline${ }^{137} \mathrm{Cs}$ & $3.08 \mathrm{E}-01$ & $1.00 \mathrm{E}+00$ & 30.81 \\
\hline${ }^{152} \mathrm{Eu}$ & $9.62 \mathrm{E}-04^{1}$ & $4.80 \mathrm{E}-04$ & 200.42 \\
\hline${ }^{154} \mathrm{Eu}$ & $5.65 \mathrm{E}-03$ & $5.20 \mathrm{E}-02$ & 10.86 \\
\hline${ }^{155} \mathrm{Eu}$ & $1.05 \mathrm{E}-02$ & $2.90 \mathrm{E}-02$ & 36.06 \\
\hline${ }^{233} \mathrm{U}$ & $1.85 \mathrm{E}-06^{1}$ & $9.00 \mathrm{E}-07$ & 205.68 \\
\hline${ }^{235} \mathrm{U}$ & $5.15 \mathrm{E}-08$ & $2.50 \mathrm{E}-07$ & 20.60 \\
\hline${ }^{237} \mathrm{~Np}$ & $9.52 \mathrm{E}-06$ & $7.40 \mathrm{E}-05$ & 12.87 \\
\hline${ }^{239} \mathrm{Pu}$ & $7.12 \mathrm{E}-04$ & $3.10 \mathrm{E}-03$ & 22.95 \\
\hline${ }^{241} \mathrm{Pu}^{2}$ & $1.19 \mathrm{E}-04$ & $2.20 \mathrm{E}-02$ & 0.54 \\
\hline${ }^{241} \mathrm{Am}$ & $1.42 \mathrm{E}-02$ & $9.00 \mathrm{E}-02$ & 15.76 \\
\hline${ }^{243 / 244} \mathrm{Cm}$ & $0.00 \mathrm{E}+00$ & $3.00 \mathrm{E}-03$ & 0.00 \\
\hline
\end{tabular}

Notes:

${ }^{1}$ Maximum value, based on a detection limit.

${ }^{2}$ Based on atomic mass unit 241 , and subtracting out the americium-241 contribution.

This DQO requires that the physical and rheological properties of the waste be measured to confirm the waste can be effectively mixed and supernatant transferred to the waste treatment plant 
RPP-SD-WM-ER-411, Rev. 1

contractor. The shear strength measurements completed on undisturbed sludge from the 1999 sampling event ranged from 23 to 93 Pascals for core 262 (riser 24A), and ranged from 79 to 1300 Pascals for core 268 (riser 15H), (approximately 180 degrees from riser 15C) (O'Rourke 2000). Particle size distribution, settling rate, viscosity, and dilution studies will be performed as designated in Herting (1999).

The HLW Feed Source DQO requires that the waste feed not contain a separable organic layer. No separable organic phase was apparent from the 1995 grab samples or the 1999 core samples.

The HLW Feed Source DQO (Nguyen 1999b), requires that the weight \% oxides in the waste be reported and compared with minimum weight percentages required in the glass. This comparison is shown in Table 1-12 below. The purpose of this exercise is to allow the prediction waste loading in the glass and the number of glass canisters each batch of waste will create. Even at $100 \%$ waste loading, many constituents will not achieve the minimum amount required in the glass (Table 1-12).

Table 1-12. HLW Glass Components Needed To Estimate The Number of Canisters Per Batch of High Level Waste Feed

\begin{tabular}{|c|c|c|c|c|c|}
\hline Dxido & $\begin{array}{l}\text { Weighi: } \% \text { ? } \\
\text { Oxire: }\end{array}$ & $\begin{array}{l}\text { Minim } \\
\text { Mriglit } \\
\text { Oxide }\end{array}$ & Oxide & $\begin{array}{l}\text { Weighit: } 90 \\
\text { Oride: }\end{array}$ & $\begin{array}{l}\text { Mininuma } \\
\text { Woighl } 9 \% \\
\text { Oxide: }\end{array}$ \\
\hline $\mathrm{Fe}_{2} \mathrm{O}_{3}$ & 10.40 & 12.5 & $\mathrm{Bi}_{2} \mathrm{O}_{3}$ & 0.01 & 2.0 \\
\hline $\mathrm{Al}_{2} \mathrm{O}_{3}$ & 11.31 & 11.0 & $\mathrm{P}_{2} \mathrm{O}_{5}$ & 0.14 & 3.0 \\
\hline $\begin{array}{l}\mathrm{Na}_{2} \mathrm{O}+ \\
\mathrm{K}_{2} \mathrm{O}\end{array}$ & 10.74 & 15.0 & $\mathrm{~F}$ & 0.13 & 1.7 \\
\hline $\mathrm{Zr}_{2} \mathrm{O}$ & 1.62 & 10 & $\mathrm{Al}_{2} \mathrm{O}_{3}+\mathrm{ZrO}_{2}$ & 12.93 & 14.0 \\
\hline $\mathrm{UO}_{2}$ & 1.29 & 8.0 & $\begin{array}{l}\mathrm{Al}_{2} \mathrm{O}_{3}+ \\
\mathrm{ZrO}_{2}+\mathrm{Fe}_{2} \mathrm{O}_{3}\end{array}$ & 23.33 & 21.0 \\
\hline $\mathrm{CaO}$ & 0.30 & 7.0 & $\mathrm{MgO}+\mathrm{CaO}$ & 0.39 & 8.0 \\
\hline $\mathrm{MgO}$ & 0.09 & 5.0 & $\mathrm{Cr}_{2} \mathrm{O}_{3}$ & 0.18 & 0.5 \\
\hline $\mathrm{BaO}$ & 0.04 & 4.0 & $\mathrm{SO}_{3}$ & 1.59 & 0.5 \\
\hline $\mathrm{CdO}$ & 0.97 & 3.0 & $\mathrm{Ag}_{2} \mathrm{O}_{3}$ & 0.08 & 0.25 \\
\hline $\mathrm{NiO}$ & 0.58 & 3.0 & $\begin{array}{l}\mathrm{Rh}_{2} \mathrm{O}_{3}+ \\
\mathrm{Ru}_{2} \mathrm{O}_{3}+\mathrm{PdO}\end{array}$ & 0.03 & 0.25 \\
\hline $\mathrm{PbO}$ & 0.09 & 1.0 & Total Other ${ }^{1}$ & 60.40 & 8.0 \\
\hline $\mathrm{TiO}_{2}$ & 0.01 & 1.0 & Total $^{2}$ & 58.66 & 40 \\
\hline
\end{tabular}

Notes:

'Total of oxides not on this table

${ }^{2}$ Total of all waste oxides exclusive of $\mathrm{Na}_{2} \mathrm{O}$ and $\mathrm{SiO}_{2}$

Equipment DQO: Were shear strength measurements performed as designated in Bloom and Nguyen (1996)?

The shear strength measurements completed on undisturbed sludge from the 1999 sampling event ranged from 23 to 93 Pascals for core 262, taken from riser $15 \mathrm{C}$, and ranged from 79 to 


\section{RPP-SD-WM-ER-411, Rev. 1}

1300 Pascals for core 268, taken from riser 15H (approximately 180 degrees from riser $15 \mathrm{C}$ ) (O'Rourke 2000). Shear strength tended to increase with sample depth in the tank.

Additional Americium-241 Analysis: Has ${ }^{241} \mathrm{Am}$ analysis been performed in duplicate on three subsamples on each solid segment for the 1999 core sample event (Poppiti 1999a)?

The ${ }^{241} \mathrm{Am}$ analysis was requested on core 262 , segments $17 \mathrm{R}$ and $18 \mathrm{R}$, and core 268 , segments 16 , 17 , and 18 , from the 1999 core sampling event. The results, which ranged from 2.53 to $111 \mu \mathrm{Ci} / \mathrm{g}$ for segment solids, are in the Analytical Results Standard Report. The data is also reported in Steen (2000a). Analysis was only performed on duplicate subsamples rather than triplicate subsamples for core 262, segment 18R, to conserve solids material, as requested in Poppiti (1999b).

ICD-23: Have the required samples been provided to the waste treatment plant contractor (BNFL 2000)?

Fourteen push-mode core segments obtained from the 1998 core sampling event provided waste treatability samples consisting of representative composites of the liquid and solid phases of tank 241-AZ-102. In addition, material from core 261 , segments 17,18 , and $18 \mathrm{R}$, were provided to meet the requirement for solids shipped to the waste treatment plant contractor.

Safety Screening DQO: Does the waste pose or contribute to any recognized safety problems?

Tank Safety Screening Data Quality Objective (Dukelow et al. 1995) identifies the data needed to screen the tank 241-AZ-102 waste for potential safety problems. These potential safety problems are exothermic conditions in the waste, flammable gases in the tank headspaces, and criticality conditions in the waste.

Reynolds et al. (1999) performed a formal review of the sampling data for tank 241-AZ-102 to determine if the safety screening DQO requirements were met. Reynolds et al. (1999) concluded that information from previous sampling events was sufficient to satisfy the safety screening requirements for tank 241-AZ-102.

The waste from the 1995 grab sampling event was applied to the safety screening DQO (Babad and Redus 1994) and results were reported in the Tank Characterization Report for Double-Shell Tank 241-AZ-102 (Ryan and Tran 1995). The fuel content of the 1995 samples was measured by differential scanning calorimetry and no exotherms were found, denoting that the fuel content of the waste was low. The sludge moisture content was found to be 51 weight percent, which satisfies the 17 weight percent water requirement of the safety screening DQO in effect at the time of sampling and analysis(Babad and Redus 1994). The estimated level of ${ }^{239 / 240} \mathrm{Pu}$ in the tank sludge, $3.14 \mu \mathrm{Ci} / \mathrm{g}$, is below the safety screening threshold of $41.3 \mu \mathrm{Ci} / \mathrm{g}$ (Babad and Redus 1994). This ${ }^{239 / 241} \mathrm{Pu}$ estimate was supported by the mean reconstituted solids ${ }^{239 / 240} \mathrm{Pu}$ value of $3.57 \mu \mathrm{Ci} / \mathrm{g}$ from the 1999 core sampling event (see Best-Basis Inventory (Radionuclides) Standard Report).

Flammable Gas DQO: Does a possibility exist for releasing flammable gases into the headspace of the tank or releasing chemical or radioactive materials into the environment (Bauer and Jackson, 1998)? 


\section{RPP-SD-WM-ER-411, Rev. 1}

The requirements to support the flammable gas issue are documented in the Data Quality Objective to Support Resolution of the Flammable Gas Safety Issue (Bauer and Jackson 1998). The Flammable Gas DQO has been extended to apply to all tanks. Analyses and evaluations will change according to program needs until this issue is resolved. Final resolution of the Flammable Gas issue is expected to be completed by September 30, 2001 (Johnson 1997).

Tank 241-AZ-102 is not on the flammable gas watch list (McCain 1999). No $\mathrm{H}_{2}$ concentration exceeding the 6,250 ppm action level, as set by Tank Waste Remediation System Final Safety Analysis Report (CHG 2000), was recorded with the Standard Hydrogen Monitoring System (SHMS) formerly installed in this tank. Following the installation of the SHMS in February 1998, the highest $\mathrm{H}_{2}$ concentration recorded for tank $241-\mathrm{AZ}-102$ is $410 \mathrm{ppm}$, on April 18, 1998. McCain (1999) lists a range from 185 parts per million (ppm) to less than $10 \mathrm{ppm}$ for headspace $\mathrm{H}_{2}$ concentration values, obtained from three grab samples between November 20, 1998 and May 21, 1999. These grab samples were taken from SHMS cabinet, as described in McCain (1999). McCain (1999) reports a $\mathrm{H}_{2}$ concentration range of $100 \mathrm{ppm}$ to $300 \mathrm{ppm}$ in the tank since May 1999, based on a Whittaker cell. The SHMS was removed from tank 241-AZ-102 on February 13, 2000.

\section{Heat Load Estimate:}

A factor in assessing tank safety is the heat generation and temperature of the waste. Heat is generated in the tanks from radioactive decay. The heat load estimate based on the process history was $46,400 \mathrm{~W}(159,000 \mathrm{Btu} / \mathrm{hr}$ ) (Agnew et al. 1997a). The tank heat load based on the Best-Basis Inventory (see Standard Report Best-Basis Inventory [Radioactive]) was 48,893 W (166,872 Btu/hr) as shown in Table 1-3. These estimates are less than the $1,172,000 \mathrm{~W}(4,000,000 \mathrm{Btu} / \mathrm{hr})$ operating specification limit for this tank (Fowler 1999).

Table 1-3. Heat Load Estimate Based on the Best-Basis Radionuclide Inventory.

\begin{tabular}{|c|c|c|c|}
\hline Rarinnuridie & Whaster lineringry & G & 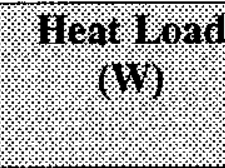 \\
\hline Strontium-90 & $4.07 \mathrm{E}+06$ & 0.00669 & 27,228 \\
\hline Cesium-137 & $4.59 \mathrm{E}+06$ & 0.00472 & 21,665 \\
\hline Total & - & - & 48,893 \\
\hline
\end{tabular}

\section{Bounding Concentration Limits:}

Sample results from the 1998 and 1999 core sampling events were screened against current bounding concentration limits used to develop the authorization source term. These bounding concentrations for aging waste tanks are found in Tables 4-1 and 4-2 of section 18 of River Protection Project Process Engineering Desk Instruction and Guidance Manual (Adams 1999). Five solid sample results from the cadmium analysis exceeded the bounding concentration limits. Notification to the managers of Nuclear Safety and Licensing and Process Engineering were made in accordance with Adams (2000). 


\section{RPP-SD-WM-ER-411, Rev. 1}

\section{Tank History}

Question 2: What is known about the history of this tank as it relates to waste behavior?

The AZ Tank Farm, located in the 200 East Area, contains two 100-series, double-shell tanks. Tank 241-AZ-102 was constructed in 1975 and has a capacity of 3,785 kL (1,000 kgal), a diameter of $22.9 \mathrm{~m}(75.0 \mathrm{ft})$, and an operating depth of $10.7 \mathrm{~m}(35.2 \mathrm{ft})$. Tank descriptions and figures are presented in standard reports Description of Tank, Tank Plan View, Tank Profile View, and Riser Configuration Table.

Tank 241-AZ-102 went into service in 1976 when it began to receive high-strontium aging waste as evaporator feed (Agnew et al. 1997b). From 1978 through 1980, residual liquor and complexant concentrate waste from 242-A Evaporator operations was added to tank 241-AZ-102. During 1983 through 1985, the tank received Plutonium-Uranium Extraction (PUREX) miscellaneous waste, evaporator feed for 242-A Evaporator campaigns, and small amounts of B Plant dilute non-complexed waste. The tank was emptied in the fourth quarter of 1985 , leaving a small heel. Between 1986 and 1990, tank 241-AZ-102 received PUREX neutralized current acid waste (NCAW) and water.

A major ventilation system upgrade was made on the AZ/AY tank farms in 1998. This upgrade included a new stack, ventilation fans, emission control equipment, emission monitoring equipment, and connecting piping (DOE/RL 1998). In addition, this modification allows for an increased flow rate from $0.4 \mathrm{~m}^{3}$ per second to $0.5 \mathrm{~m}^{3}$ per second.

Tank 241-AZ-102 is still active, and periodically receives small volumes of condensate from the AY and AZ tank farms through AZ-151. The tank currently contains 3,682 kL (973 kgal) of NCAW, also identified as aging waste, and is listed as sound (Hanlon 2000).

\section{Tank Comparisons}

Question 3: What other tanks have similar waste types and waste behaviors, and how does knowledge of the similar tanks contribute to the understanding of this tank?

The waste types listed for tank 241-AZ-102 in Agnew et al. (1997a) are A1 salt slurry from the 242-A Evaporator, slurried PUREX Plant sludge, B Plant low-level waste, PUREX low-level waste, and high-level NCAW. With the exception of the NCAW, the waste types were all added preceding the tank waste removal in 1986. Any remaining inventory from these wastes would be present in a small heel left prior to the addition of the NCAW waste. Sampling data from this portion of the tank is inconclusive, and the composition of the waste heel is unknown. Therefore, information from tanks with similar waste types other than the NCAW would add significant knowledge regarding the waste in tank 241-AZ-102.

The predominant waste type for tank $241-\mathrm{AZ}-102$ is the NCAW waste. One other tank, tank 241-AZ-101 is currently being used for aging waste storage. Between 1983 and 1986, NCAW waste was added to tank 241-AZ-101. Tank 241-AZ-102 received NCAW between 1986 and 1990. The exact composition of $\mathrm{NCAW}$ varied with each processing run. 


\section{RPP-SD-WM-ER-411, Rev. 1}

Tank 241-AZ-102 contains more sludge than tank 241-AZ-101 (397 $\mathrm{kL}$ versus $197 \mathrm{~kL}$ in the respective tanks). The sludge volume in tank 241-AZ-102 is larger than in tank 241-AZ-101 for several reasons. First, tank 241-AZ-102 contained a larger initial waste heel at the time PUREX waste was added than tank 241-AZ-101. Second, a larger fraction of the aluminum precipitated in tank 241-AZ-102 than Tank 241-AZ-101 as a result of a lower hydroxide concentration. Third, more ferrous sulfamate was used to process the reactor fuels associated with the tank 241-AZ-102 waste because of the implementation of neptunium recovery.

A comparison was done on the recent analytical data from tanks 241-AZ-101 and 241-AZ-102 from samples taken in 1998 and 1999 . The data from the two tanks agreed closely in many areas, including the radionuclide data. Notable exceptions to this agreement include ${ }^{239 / 240} \mathrm{Pu}$ in tank $241-$ AZ-102 liquid layer, phosphate and aluminum in tank 241-AZ-101 liquid layer and sulfate and zirconium in tank 241-AZ-101 solid layer. These exceptions were at least 3 times higher in concentration than that of the other tank.

\section{Disposal Implications}

Question 4: Given what is known about the waste properties and waste behaviors in this tank, what are the implications of the waste properties and behaviors to the waste retrieval/processing methodologies and equipment selection?

Tank 241-AZ-102 has been selected as a Phase I source tank for Envelope D High Level Waste (HLW) sludge and Envelope B Low-Activity Feed (LAW) liquid. The tank contains 3,285 kL $(868 \mathrm{kgal})$ of supernatant and $397 \mathrm{~kL}$ (105 kgal) sludge, and the two waste phases will be mixed prior to direct delivery of the tank contents to the vitrification contractor. Six batches of waste are expected for the tank 241-AZ-102.

Some physical and rheological measurements have not been performed for the samples as of the TIR publication date and could not be compared to limits set for those properties. Solids composite material and supernatant were archived for solubility screening per Person (1999) and retrieval testing per Herting (1999).

The shear strength measurements completed on undisturbed sludge from the 1999 sampling event ranged from 23 to 93 Pascals for core 262 (riser 24A), and ranged from 79 to 1300 Pascals for core 268 (riser $15 \mathrm{H}$ ), (approximately 180 degrees from riser 15C). The shear strength measurements tended to increase with sample depth in the tank. Shear strength measurements are an indicator of the ability of a mixer pump to mobilize the waste. Potential problems with mixing the lower third of the tank waste should be anticipated. The retrieval efficiency expected for the tank 241-AZ-102 solids is 80 percent (Kirkbride et al. 2000).

A visible organic layer was not apparent in the liquid from the 1995 grab sample event or the 1999 core sampling event (CHG 2000). Organics should not impact retrieval and disposal of tank 241-AZ-102 waste. The flammable gas concentrations measured in the tank headspace were low (3 percent of the LFL) prior to sampling events (See Industrial Hygiene (IH) Sniff Standard Report). The vapors were measured during steady-state conditions; the waste may behave differently during retrieval operations such as mixing and pumping. 
RPP-SD-WM-ER-411, Rev. 1

The waste designated to qualify under Envelope B LAW liquid and Envelope D HLW sludge is out of specification. The values given for radionuclides that exceeded feed limits were based on detection limits, and if better detection limits are achieved for these analyte in the future, it may be shown that the waste is within the envelope limits. The non-radionuclide Group-One analytes met the Envelope B limits and the Envelope D limits, with the exception of sulfate $(110 \%)$ sodium ratios for the liquid. There are no plans to alter the waste composition to bring out-of-specification feed into compliance (Kirkbride et al. 2000).

Two mixer pumps and a transfer pump and jumpers will need to be installed prior to the delivery of the waste to the vitrification contractor (Kirkbride et al. 2000).

\section{Scientists Assessment of Data Quality and Quantity}

Question 5: Given the current state of understanding of the waste in this tank on the one hand and the information drivers on the other; should additional tank data be sought via sampling/analysis from a strictly technical point-of-view? Can the waste behavior in this tank be adequately understood by other means (eg. archive samples, tank grouping studies, modeling) without additional sampling and analysis? If so, what characteristics of the tank waste lend themselves to a nonsample alternative? Is the quality of the data from this tank adequate from a field sampling and analytical laboratory point-of-view? Are there any clarifications or explanations needed for the data tables and figures?

The following DQOs and waste issues have been addressed for this tank and accepted by the Project Hanford Management Contractor (PHMC) River Protection Project (RPP): Low Activity Waste and High Level Waste Feed Data Quality Objectives (WIT DQO), Data Quality Objectives for TWRS Privatization Phase 1: Confirm Tank T is an Appropriate Feed Source for High-Level Waste Feed Batch X (HLW DQO), Data Quality Objectives for TWRS Privatization Phase 1: Confirm Tank T is an Appropriate Feed Source for Low-Activity Waste Feed Batch X (LAW DQO), Characterization Data Needs for Development, Design, and Operation of Retrieval Equipment Developed through the Data Quality Objective Process (Equipment DQO), Interface Control Document-23 (ICD-23) issue, Additional Americium-241 analysis, Air Emissions DQO, Dangerous Waste DQO, Tank Safety Screening DQO, and Flammable Gas DQO. Additional analyses necessary to satisfy DQO requirements for this tank include measurements of physical and rheological properties of the waste to confirm that the waste can be effectively mixed and transferred to the waste treatment plant contractor. Archived solids composite material and supernatant from the tank 241-AZ-102 1999 core sampling event should adequately provide the samples needed for the additional analyses.

One core sample was requested to be taken from tank 241-AZ-102 (Rasmussen 1998) to provide waste treatability samples to the waste treatment plant contractor. Seventeen segments were expected and obtained for a full core profile from the tank. Push-mode core sampling between July 23, 1998 and July 31, 1998, recovered core 254 from riser 15J. The solid segments were combined to form a composite and a subsample was submitted to the 222-S Laboratory for analyses. The drainable liquid from segments 2,7 , and 14 was also submitted to the laboratory for analyses. These analyses were used to determine the homogeneity of the supernatant and the shipping criteria.

The objective for the 1999 sampling event was to obtain two full vertical profiles of the waste in tank 241-AZ-102 and provide sufficient material for the chemical analyses and tests required to satisfy the applicable DQOs (Rasmussen 2000a). Additional solids material was also obtained to ship to the 


\section{RPP-SD-WM-ER-411, Rev. 1}

waste treatment plant contractor. Push-mode core samples were requested from risers $15 \mathrm{C}, 15 \mathrm{H}$, and $24 \mathrm{~A}$. Core 262 from riser $24 \mathrm{~A}$ consisted of twenty segments, comprising a full core. Twenty segments were recovered from core 261 in riser 15C. During the sampling event, each of the two sludge segments from core 261 (segments 16 and 17) were sent to the waste treatment plant contractor in order to meet the sample shipment schedule required per Poppiti (1999a). A third core sample (core 268) consisting of segments $16,17,17 \mathrm{R}$, and 18 was taken from riser $15 \mathrm{H}$. The core 268 segment material was combined with the core 261 supernatant to constitute a second full core for tank 241-AZ-102.

The average waste yield from each core segment (where waste was recovered) from the 1999 sampling event was 95 percent. No waste material was recovered for core 261, segment 9 , or for core 262 , segment 14 . The samplers for these segments were found empty; the sample valves were open upon receipt at the 222-S Laboratory. The drainable liquid homogeneity criteria were met for the supernatant in the tank (Rasmussen 2000b), and the liquid from the recovered segments is representative of the material from core 261 , segment 9 , and core 262 , segment 14 .

Two core composites were created in accordance with the Low Activity Waste and High Level Waste Feed Data Quality Objective (Patello et al. 1999). Individual solids composites were prepared for cores 262 and 268 as described in Rasmussen (2000b). Approximately $120 \mathrm{~g}$ of each core solids composite were combined with supernate to form core analytical composites.

The core 262 analytical composite was created by combining approximately $54 \mathrm{~mL}$ of liquid from each of the core 262 segments 2 through 16 , with the exception of segment 14 , and adding $120 \mathrm{~g}$ of the core 262 solids composite material. Core 262 , segment 13 supernate was used to represent core 262 , segment 14 since sample material was not recovered for core 262, segment 14 . Core 262, segment 17 , contained solids and liquid waste. Core 262, segment 16 , supernatant was used to represent the $17.6 \mathrm{~mL}$ of core 262 , segment 17 liquid required for the composite, based on the 6.39 in. if liquid waste from the segment. Because core 262 , segment 1, represented only 12 in. of waste, $33 \mathrm{~mL}$ were included from this segment.

The core 268 analytical composite was created by combining supernates from core 261 with solids from core 268. Approximately $40.8 \mathrm{~mL}$ of liquid from each of the core 261, segments 2 through 15 , with the exception of segment 9 , were added to $120 \mathrm{~g}$ of the core 268 solids composite material. Core 261 , segment 8 , supernate was used to represent core 268 , segment 9 , since sample material was not recovered for core 261 , segment 9 . Because core 268 , segment 16 , contained both solids and liquid waste, approximately $31 \mathrm{~mL}$ of core 261 , segment 16 , supernatant were used to represent the 14.48 in. of supernate in core 268 , segment 16 . Because core 268 , segment 1 , represents 12 in. of supernate, approximately $25.8 \mathrm{~mL}$ of core 261 , segment 1 , supernate were included in the core 268 composite.

Each analytical composite was shaken to form a slurry, then centrifuged to separate the two phases. Each phase was divided into three separate subsamples for laboratory analysis (Steen 2000a). Because dilution is not anticipated to be required for retrieval and transfer of the contents of this tank, the analytical composites were also used to satisfy Nguyen (1999a) and Nguyen (1999b). The remaining solids composite material and supernatant were archived for solubility screening per Person (1999) and retrieval testing per Herting (1999). 


\section{Data Quality}

The data obtained in the 1998 and 1999 core sampling events were collected and analyzed with approved and recognized sampling and laboratory procedures. The core analyses were performed in accordance with the sampling and analysis plans (Rasmussen 1998 and Rasmussen 2000a). The laboratory procedures for the core sample analysis can be found in the standard report Analytical Methods and Procedures. Quality Control (QC) parameters assessed in conjunction with tank 241-AZ-102 samples included standard recoveries, spike recoveries, relative standard deviations, and blanks. Appropriate QC footnotes were applied to data outside QC parameter limits as shown in the standard report Analytical Results. Analytical results and data quality for the core samples are discussed in the tank 241-AZ-102 data package (Steen 2000a).

The majority of QC results were within the boundaries specified in the sampling and analysis plans. Small discrepancies noted in the analytical reports and footnoted in the Analytical Results Standard Report should not impact the data validity or use. A brief discussion of these small discrepancies is presented below.

\section{Hydroxide Analyses}

High relative standard deviations (RSDs) were reported for the drainable liquid subsamples. These RSDs were attributed to sample inhomogeneity and no reanalysis was requested.

\section{Ion-Specific Electrode (ISE) analyses}

High RSDs were reported for four sets of subsamples for ammonia. The results for these samples were less than or near the detection limit, which decreased the precision of the analysis. Therefore, no ammonia reanalysis was requested. Three subsamples with results less than the detection limit had high standard recovery results ( $>120$ percent).

\section{Spectrophotometric Analysis for Cyanide}

A high RSD was reported for one set of solid subsamples. The results for these samples were less than or near the detection limit, which decreased the precision of the analysis. Therefore, no reanalysis was requested.

\section{Cold Vapor AA for Mercury}

A high RSD was reported for one set of liquid subsamples. The results for these samples were less than or near the detection limit, which decreased the precision of the analysis.

\section{Anions by Ion Chromatography (IC)}

For some samples, the blank value was reported as non-applicable. The continuous calibration blank result may be substituted for the blank result.

High RSDs were reported for the chloride results. No reanalysis was requested, as the results for these samples were less than or near the detection limit, which decreased the precision of the analysis. 


\section{RPP-SD-WM-ER-411, Rev. 1}

\section{Inductively Coupled Plasma (ICP) Analyses}

Analytes measured by ICP with a high RSD ( $>15$ percent) for the liquid core composite subsamples included $\mathrm{Al}, \mathrm{B}$, and $\mathrm{Si}$. The solid core composite subsamples for $\mathrm{B}, \mathrm{P}, \mathrm{Pb}$, and $\mathrm{Si}$ had high $\mathrm{RSD}$ values. The RSD failures for B and Si may have been because of leaching from the digestion vessels or glass vials used to store the samples. Some metals in the subsamples may not have been uniformly dissolved by the acid digestion process. As the concentration of many of these analytes was less than ten times the detection limit, no repreparation or reanalysis was requested.

In addition, a high RSD ( $>3.5$ percent) was reported for $\mathrm{Na}$ on both the liquid and solid core composite subsamples. No repreparation or reanalysis was requested, as $\mathrm{Na}$ contamination is difficult to avoid.

Matrix spike recoveries outside of the $75 \%$ to $125 \%$ control limits (Rasmussen 2000a) were reported for some ICP results. The spike failures for $\mathrm{Al}, \mathrm{B}, \mathrm{Cd}, \mathrm{Ca}, \mathrm{Fe}, \mathrm{Pb}, \mathrm{Ni}, \mathrm{P}, \mathrm{Si}, \mathrm{Ag}, \mathrm{Na}, \mathrm{S}$, $\mathrm{U}$, and $\mathrm{Zr}$ were attributed to the high concentration of these analytes in the samples with respect to the amount of spike standard added. The spike failures for As, Eu, P, Se, Th, and Y were because of matrix interference either from the samples or the sample preparation reagents. A post-digestion spike analysis was performed as an additional instrument performance check. The post digestion spike recoveries were within the required limits.

It is difficult to add sufficient spike to perform a meaningful analysis with high concentrations of analytes. A comparison of the sample results to those of a serial dilution of the sample is done to assess the accuracy of the measurement for these analytes. The serial dilution was performed by preparing and analyzing an additional five-fold dilution of the sample. The serial dilution results were within +10 percent of the undiluted sample results for all analytes except $\mathrm{Eu}, \mathrm{Si}$, Th, and $\mathrm{K}$. The undiluted results for these analytes were close to the detection limit, contributing to the decrease in precision with the serial dilution.

Standard recoveries for $\mathrm{Sb}, \mathrm{As}, \mathrm{Bi}, \mathrm{B}, \mathrm{Ca}, \mathrm{Cd}, \mathrm{Cr}, \mathrm{Co}, \mathrm{Pb}, \mathrm{Mn}, \mathrm{Mo}, \mathrm{Na}, \mathrm{Ni}, \mathrm{P}, \mathrm{Se}, \mathrm{Si}, \mathrm{Tl}$, and $\mathrm{Zn}$ were outside the limits of $80 \%$ to $120 \%$ for the acid digestion portion of the subsamples. The acid digestions were performed in the hot-cells using remote equipment. Therefore, the accuracy needed to weigh and measure could not be achieved. No reanalysis was requested.

\section{Inductively Coupled Plasma Spectrophotometer/Mass Spectrophotometer (ICP/MS)}

No ICP/MS analyses for Pt were done, since $\mathrm{Pt}$ is not completely digested using the current acid digestion method.

The analytes As and V required isobaric correction for the presence of chlorinated polyatomic interference. It should be noted the isobaric corrections can be overestimated, leading to a bias low.

Significant differences were noted between the two isotopes of $\mathrm{Sb}$, Atomic Mass Unit (AMU) 121 and AMU 123. The AMU 123 values were approximately five times higher than the AMU 121 values. This discrepancy is likely due to a polyatomic interference on AMU 123. Therefore, the AMU 121 results were reported for $\mathrm{Sb}$. Two primary isotopes for the analyte Eu (AMU 151 and AMU 153) were monitored, and the reported result was the sum of the two isotopes. 


\section{RPP-SD-WM-ER-411, Rev. 1}

Difficulty in determining Pd accurately was noted (Steen 2000a), as a bias high was identified in the analytical method. Because of the difficulty in determining Pd accurately, Ru may also be biased high.

High RSDs (>15\%) were reported for $\mathrm{Ba}, \mathrm{La}, \mathrm{Sb}, \mathrm{Ce}, \mathrm{Zr} /{ }^{9} \mathrm{Sr}$ (AMU 90), ${ }^{237} \mathrm{~Np},{ }^{235} \mathrm{U},{ }^{236} \mathrm{U}$, and ${ }^{238} \mathrm{U}$ on the liquid composites, and for $\mathrm{Sb}$ and $\mathrm{Se}$ on the solids composites. The RSDs were attributed to sample inhomogeneity, and no reanalysis was requested.

Spike recoveries outside of the required range (70\% to $130 \%)$ were reported for $\mathrm{Ce}, \mathrm{La}, \mathrm{Pr}$, and AMU 90. The results for these analytes were near or less than the detection limit, which decreased the precision of the analysis. No reanalysis was requested.

Standard recoveries for ${ }^{235} \mathrm{U}$ were reported as outside of the required range of $90 \%$ to $110 \%$. The value of the standard was close to the detection limit, decreasing the precision of the analysis. No reanalysis was requested.

\section{Total Inorganic Carbon/Total Organic Carbon (TIC/TOC) Analyses}

The RSD value associated with two sets of TOC solid composite subsamples are above the tank sampling and analysis plan (TSAP) limit (Rasmussen 2000a). No reanalysis was requested because of insufficient sample material available.

\section{Alpha Radiochemistry}

A high RSD was reported for one set of liquid subsamples. This was attributed to sample inhomogeneity and no reanalysis was requested.

\section{Gamma Energy Analysis (GEA)}

A small amount of contamination was detected in the preparation blank. However, the level of contamination was insignificant when compared to the associated sample results and does not effect the usability of the data.

A RPD of $31.2 \%$ for ${ }^{60} \mathrm{Co}$ was reported for the core 254 solid composite subsample. The high RPD was attributed to sample inhomogeneity, and no reanalysis was requested.

The minimum detection limit for ${ }^{60} \mathrm{Co}$ and ${ }^{154 / 155} \mathrm{Eu}$ was slightly higher than the TSAP (Rasmussen 2000a) limit for sample S00T000202 (core 262 liquid composite).

\section{Carbon $14\left({ }^{14} \mathrm{C}\right)$}

A standard recovery outside of the required range $(80 \%$ to $120 \%)$ was reported for one set of solid subsamples. The standard recovery was within the $222-\mathrm{S}$ laboratory control limits, and no reanalysis was requested. 


\section{Alpha Energy Analysis (AEA)}

\section{RPP-SD-WM-ER-411, Rev. 1}

High RSDs ( $>15 \%$ ) were reported for ${ }^{238 / 239} \mathrm{Pu}$ on the 1999 solid composite mean. No reanalysis was requested.

The TSAP (Rasmussen 2000a) also required total carbon analysis. There was insufficient sample material to perform this analysis.

Some analytical results from the sampling event were flagged by a computer algorithm using internal QC standards. These results were reviewed to determine if the data were compromised, and if so, the anomalous value will be removed from the Analytical Results Standard Report. All fusion digest nickel results will be removed from the Analytical Results Standard Report because of sample contamination from the use of nickel crucibles for fusion analyses. The primary zinc value for core 262 , segment 16, (sample number S99T001399) was reported as $24.1 \mu \mathrm{g} / \mathrm{mL}$. The duplicate for this sample and all other liquid zinc results for 241-AZ-102 were reported as below the detection limit. The average detection limit for this data set for zinc was less than $2.0 \mu \mathrm{g} / \mathrm{mL}$. The primary acid digest calcium value of $11,100 \mu \mathrm{g} / \mathrm{g}$ for core 268 , segment 18 , lower half (sample number S99T001887), and the duplicate fusion calcium value of $9,650 \mu \mathrm{g} / \mathrm{g}$ from core 268 , segment 18 , upper half (sample number S99T001877), both exceeded the surrounding data by a factor of two or more. The zinc value of $24.1 \mu \mathrm{g} / \mathrm{mL}$ and the calcium values of $11,100 \mu \mathrm{g} / \mathrm{g}$ and $9,650 \mu \mathrm{g} / \mathrm{g}$ were determined suspect (Rasmussen 2000c) and will be removed from the Analytical Results Standard Report.

Oxalate results from the ion chromatography re-analyses performed on the 1999 core composite solids in May, 2000, are nearly two orders of magnitude less than the other oxalate data for these sample events. These re-runs were performed to improve detection limits for low-molecular weight organic anions including citrate, imimodiacetate, and nitrilotriacetate. A review of the total organic carbon results confirmed that these secondary analyses were not needed, whereupon the results were declared "opportunistic." A review of the raw data revealed that the sulfate results for these reanalyses are also two orders of magnitude less than the initial data, suggesting that a dilution adjustment may be required. The Laboratory rejected the sulfate values for these ion chromatography runs, and did not investigate the opportunistic results further. Therefore, the results from the May 2000 ion chromatography re-runs will be removed from the Analytical Results Standard Report per Rasmussen (2000c).

\section{Clarification and Explanation of Data Tables and Figures}

Description of Tank Standard Report: The total waste volume of 3,682 kL (973 kgal) and the supernate volume of $3,285 \mathrm{~kL}$ ( $868 \mathrm{kgal}$ ) shown in this standard report do not agree with the Hanlon (2000) volume. The volumes were adjusted to account for recent condensate additions from 241-AZ-151. The sludge volume also differs between the standard report and Hanlon (2000) report. The sludge volume in the standard report was derived from available sludge level measurements. The updated volumes will be reflected in a future revision to Hanlon (2000).

The 241-AZ-102 HTCE Surface Levels and 241-AZ-102 Average Monthly Tank Surface Level standard reports: These reports show that the surface level has fluctuated substantially since the last PUREX waste transfer into the tank in 1986. These fluctuations are attributed to evaporation and 


\section{RPP-SD-WM-ER-411, Rev. 1}

periodic ventilation system condensate additions from tank 241-AZ-151. A record of evaporation and water additions can be found in the Tank Transfers standard report. The decrease in tank waste level and volume from January 1996 to February 1998 is attributed to a net evaporative loss of water from the tank waste. The increase in tank waste level and volume from March 1998 to August 2000 is attributed to a net gain of water from condensate added to the tank.

The 241-AZ-102 Tank Temperature Profile standard report: This profile reports the maximum temperature for the thermocouples in the tank waste as a function of time. The fluctuations in waste temperature evident in the graph are attributed to seasonal temperature variations. The general decrease in waste temperature is attributed to the decay of radionuclides in the waste.

The 241-AZ-102 Core Profiles standard report: The sampling dates shown on this report are inclusive of, but may not be identical with, the sample dates reported on the segment chain-of-custody forms.

The Tank 241-AZ-102 Transfers (1994 to present) standard report: This report ignores individual waste volume transfers of less than $11 \mathrm{~kL}(3 \mathrm{kgal})$. Consequently, the correct total of flush water transferred into the tank over the time period shown is $1,245 \mathrm{~kL}$ ( $329 \mathrm{kgal})$. Over the same period of time, $1,287 \mathrm{~kL}$ ( $340 \mathrm{kgal}$ ) of water is estimated to have evaporated from the tank.

\section{Unique Aspects of the Tank}

Question 6: What are unique chemical, physical, historical, operational or other characteristics of this tank or its contents?

Tank 241-AZ-102 is relatively unique in that it is a double-shell tank designed to provide storage space for high-level aging waste generated at the Plutonium-Uranium Extraction (PUREX) Plant. Aging waste tanks have a special support system to allow the tanks to store high-heat generating wastes with minimum probability of loss of integrity. The support system includes a tank preheating system comprised of a steam coil, a waste mixing system comprised of 22 airlift circulators, and an exhaust condenser system to control condensate in the exhaust stream. The only double-shell tanks containing these systems are tanks 241-AY-101, 241-AY-102, 241-AZ-101, and 241-AZ-102.

The current tank 241-AZ-102 contents consists of NCAW and dilute noncomplexed waste. The majority of the NCAW waste is limited to tanks 241-AZ-101 and 241-AZ-102. The NCAW waste resulted from the first-cycle solvent extraction step in the PUREX processing of zirconium-clad $\mathrm{N}$ Reactor fuel elements. Following the removal of cladding, irradiated nuclear fuel was dissolved in nitric acid. The dissolved nuclear fuel was then fed to a solvent extraction system that removed most of the neptunium, plutonium, and uranium. The waste stream was then concentrated, and most of the nitric acid was recovered. The waste was then neutralized with sodium hydroxide before being transferred to the aging-waste tanks.

During the additions of the NCAW waste between 1986 and 1990, solids from the waste additions settled to the bottom of the tank, creating a sludge waste layer below the supernatant. It is shown in the sampling analytical results that the upper portion of the sludge waste layer has a significantly higher concentration of aluminum. It is assumed that over time the aluminum in the supernate is precipitating out of the liquid and settling on the sludge layer in the tank. 


\section{RPP-SD-WM-ER-411, Rev. 1}

The most recent in-tank photographs available, taken in October 1984, show a level liquid surface. The waste seen in the October 1984 photographs was transferred out in 1986, and NCAW waste has since been added to the tank. The sampling extrusion results show a clear yellow supernatant in the upper segments, and a brown sludge slurry in the lower two to three segments. Core 268, segment 18 , was divided into two subsamples based on the observation that the lower three inches of light brown sludge slurry differed in appearance from the rest of the dark brown material in the sample. It may be postulated that the lower three inches comprises material from the waste heel left after the tank waste removal in 1986, prior to the addition of the NCAW waste to tank 241-AZ-102.

\section{Means and Confidence Intervals}

Question 7: What statistical model was used to generate the means and confidence intervals? What data was included in the calculations?

A nested analysis of variance (ANOVA) model was fit to the data from the solid portion and liquid portion of the laboratory samples. Mean analyte concentrations, and $95 \%$ confidence intervals on the mean, were estimated using results from the ANOVA. Two variance components were estimated and used in the computations. The variance components represent concentration differences between laboratory samples and between analytical replicates.

The model is:

where

$$
\begin{gathered}
Y_{i j}=\mu+L_{i}+A_{i j}, \\
i=1,2, \ldots, a ; j=1,2, \ldots, n_{i} ;
\end{gathered}
$$

$\begin{array}{ll}\mathrm{Y}_{\mathrm{ij}} & =\text { concentration from the } \mathrm{j}^{\text {ht }} \text { analytical result from the } \mathrm{i}^{\text {ih }} \text { riser } \\ \mu & =\text { the mean } \\ \mathrm{L}_{\mathrm{i}} & =\text { the effect of the } \mathrm{i}^{\text {dh }} \text { laboratory sample } \\ \mathrm{A}_{\mathrm{ij}} & =\text { the analytical error } \\ \mathrm{a} & =\text { the number of laboratory samples } \\ \mathrm{n}_{\mathrm{i}} & =\text { the number of analytical results from the } \mathrm{i}^{\text {th }} \text { laboratory sample. }\end{array}$

The variable $L_{i}$ is a random effect. This variable and $A_{i j}$ are assumed to be uncorrelated and normally distributed with means zero and variances $\sigma^{2}(\mathrm{~L})$, and $\sigma^{2}(\mathrm{~A})$, respectively.

The restricted maximum likelihood method (REML) was used to estimate the mean concentration and standard deviation of the mean for all analytes that had $50 \%$ or more of their reported values greater than the detection limit. The mean concentrations and standard deviations of the mean were used to calculate the $95 \%$ confidence intervals. The following table gives the estimate of the mean, degrees of freedom, and confidence interval on the mean. 
RPP-SD-WM-ER-411, Rev. 1

Some analytes had results that were below the detection limit. In these cases the value of the detection limit was used for non-detected results. For analytes with a majority of results below the detection limit, a simple average is reported.

The lower and upper limits, LL(95\%) and UL(95\%), of a two-sided $95 \%$ confidence interval on the mean were calculated using:

$$
\begin{array}{r}
\operatorname{LL}(95 \%): \hat{\mu}-\mathrm{t}_{(\mathrm{df}, 0.025)} \times \hat{\sigma}(\hat{\mu}) \\
\mathrm{UL}(95 \%): \hat{\mu}+\mathrm{t}_{(\mathrm{df}, 0.025)} \times \hat{\sigma}(\hat{\mu}) .
\end{array}
$$

In these equations, $\hat{\mu}$ is the REML estimate of the mean concentration, $\hat{\sigma}(\hat{\mu})$ is the REML estimate of the standard deviation of the mean, and $t_{(d f, 0,025)}$ is the quantile from Student's $t$ distribution with $d f$ degrees of freedom. The degrees of freedom are the number of laboratory samples with data minus one. In cases where the lower limit of the confidence interval was negative, it was reported as zero.

The means for each data set are listed separately in the 241-AZ-102 Means and Confidence Intervals Standard Report. For the solids, the Tank 241-AZ-102 95 Percent Two-Sided Confidence Interval for the Mean Concentration for Solid 1999 Composite table refers to data generated from the core 262 solids composite and the tank composite solids. The Tank 241-AZ-102 95 Percent Two-Sided Confidence Interval for the Mean Concentration for Solid 1999 Segment table refers to data generated from core 262, segments $17 \mathrm{R}$ and 18R; and core 268, segments 16, 17, and the upper half of segment 18. The Tank 241-AZ-102 95 Percent Two-Sided Confidence Interval for the Mean Concentration for Solid Core 254 Composite table refers to data generated from core 254 solid composite material, recovered during the 1998 sampling event.

For the liquids, the Tank 241-AZ-102 95 Percent Two-Sided Confidence Interval for the Mean Concentration for Liquid Core Composite Data table refers to data generated from the core 262 liquid composite and the tank composite liquid. The Tank 24I-AZ-102 95 Percent Two-Sided Confidence Interval for the Mean Concentration for Liquid Segment Level Data table refers to data generated from drainable liquid for core 261, segments 1 through 16; core 262, segments 1 through 18, and segments 17R and 18R; and core 268 segments 16 and 17R. The Tank 24I-AZ-102 95 Percent Two-Sided Confidence Interval for the Mean Concentration for Liquid Core 254 table refers to data generated from drainable liquid for core 254, segments 2, 7, and 14. The Tank 241-AZ-102 95 Percent Two-Sided Confidence Interval for the Mean Concentration for Liquid 1995 Grab Sample table refers to data generated from the AZ1021, AZ1022, and AZ1023 grab samples recovered in 1995.

\section{Best-Basis Inventory Derivation}

Question 8: What is the source data used to derive this tank's Best-Basis inventories by mass ( $\mathrm{kg}$ ) and activity (Ci) for the standard list of 25 chemicals and 46 radionuclides?

The Best-Basis Inventory (BBI) effort involves developing and maintaining waste tank inventories comprising 25 chemical and 46 radionuclide components in the 177 Hanford Site underground storage tanks. These best-basis inventories provide waste composition data necessary as part of the 


\section{RPP-SD-WM-ER-411, Rev. 1}

River Protection Project (RPP) process flowsheet modeling work, safety analyses, risk assessments, and system design for retrieval, treatment, and disposal operations.

Development and maintenance of the best-basis inventory is an on-going effort. Since new sample data were recently made available for tank $241-\mathrm{AZ}-102$, a re-evaluation of the best-basis inventories was performed and is documented in the following text. The following information was used in this evaluation:

- Tank 241-AZ-102 statistical means based on the 1999 core sample analytical results (cores 261, 262, and 268) (see Means and Variances Standard Report).

-Tank 241-AZ-102 Savannah River Technical Center (SRTC) analytical means from the 1998 core sample (core 254) composites.

-Hanford Defined Waste (HDW) model double-shell tank 241-AZ-102 Supernatant Mixing Model (SMM) inventory estimates (Agnew et al. 1997a).

-Process knowledge based on the ORIGEN2 model inventory for fuel processed through PUREX during the time period of the PUREX waste additions to tank 241-AZ-102 (Wootan 1997).

The following table represents how the available data were used to derive best-basis inventories for tank 241-AZ-102.

Table 8-1. Tank 241-AZ-102 Best-Basis Inventory Source Data(2 pages).

\begin{tabular}{|c|c|c|c|c|}
\hline Waste Thase & Waste I Ine & 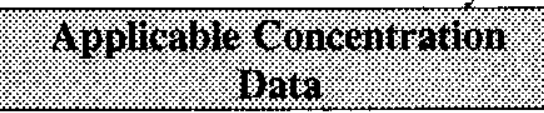 & $\begin{array}{l}\text { Assoetitad } \\
\text { Density. }\end{array}$ & $\begin{array}{l}\text { Associated } \\
\text { Volume }\end{array}$ \\
\hline \multirow[t]{4}{*}{ Supernatant } & \multirow{4}{*}{$\begin{array}{l}\text { Neutralized } \\
\text { Current Acid } \\
\text { Waste } \\
\text { (NCAW) }\end{array}$} & $\begin{array}{l}\text { Mean concentrations for } 1999 \\
\text { core segment drainable liquid }\end{array}$ & $1.14 \mathrm{~g} / \mathrm{mL}$ & \multirow[t]{4}{*}{$\begin{array}{l}3,285 \mathrm{~kL} \\
(868 \mathrm{kgal})\end{array}$} \\
\hline & & $\begin{array}{l}\text { Mean concentrations for } 1999 \\
\text { core composite centrifuged } \\
\text { liquid }\end{array}$ & & \\
\hline & & $\begin{array}{l}\text { HDW model } 241-\mathrm{AZ}-102 \\
\text { SMM Composite Inventory }\end{array}$ & $1.05 \mathrm{~g} / \mathrm{mL}$ & \\
\hline & & $\begin{array}{l}\text { Mean concentrations for } 1998 \\
\text { SRTC filtered liquid composite }\end{array}$ & $1.15 \mathrm{~g} / \mathrm{mL}$ & \\
\hline \multirow[t]{4}{*}{ Sludge } & \multirow{4}{*}{$\begin{array}{l}\text { Neutralized } \\
\text { Current Acid } \\
\text { Waste } \\
\text { (NCAW) }\end{array}$} & $\begin{array}{l}\text { Mean concentrations for } 1998 \\
\text { SRTC core composite dried } \\
\text { solids }\end{array}$ & \multirow[t]{4}{*}{$1.47 \mathrm{~g} / \mathrm{mL}$} & \multirow[t]{4}{*}{$\begin{array}{l}397 \mathrm{~kL} \\
(105 \mathrm{kgal})\end{array}$} \\
\hline & & $\begin{array}{l}\text { Mean concentrations for } 1999 \\
\text { core segment solids }\end{array}$ & & \\
\hline & & $\begin{array}{l}\text { Mean concentration for } 1999 \\
\text { core composite solids }\end{array}$ & & \\
\hline & & $\begin{array}{l}\text { Tank Process Knowledge, } \\
\text { Estimated BBI Solids } \\
\text { Radionuclide Concentrations }\end{array}$ & & \\
\hline
\end{tabular}


RPP-SD-WM-ER-411, Rev. 1

Table 8-1. Tank 241-AZ-102 Best-Basis Inventory Source Data(2 pages).

\begin{tabular}{|c|c|c|c|c|}
\hline 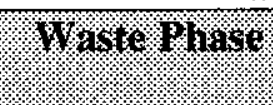 & 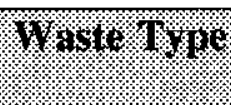 & 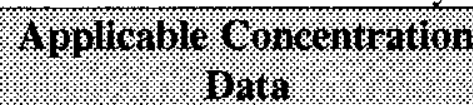 & (6roginted & (x)oogited \\
\hline Total Tank & & & & $\begin{array}{l}3,682 \mathrm{~kL} \\
(973 \mathrm{kgal})\end{array}$ \\
\hline
\end{tabular}

The waste phase designations in Table 8-1 were based on core sampling extrusion results. Visual observations of the core extrusions indicated that only supernatant and sludge wastes were present. The observations were supported by analyte concentrations and process history (Agnew et al. 1997a). The waste type designation of neutralized current acid waste (NCAW) for the supernatant and sludge waste phases was based on the waste additions from PUREX between 1986 and 1990. Prior to the additions of NCAW waste the tank was emptied, leaving a minimal heel. For the purpose of the BBI, the NCAW sludge waste concentrations were considered representative of the tank waste heel. The waste type designation for tank 241-AZ-102 in Hanlon (2000) was aging waste, synonymous with the NCAW waste type.

The 1999 core samples were analyzed on the segment and composite basis. The mean values from the solids and liquid 1999 segment data used for the BBI can be found in the Means and Variances Standard Report. The 1999 core composites were prepared by combining the segment material from each core, and separating the liquid and solids by centrifugation. The means were calculated combining the values from the tank composite (core 261 liquid and core 168 solids material) and the core 262 composite. The analyte means for the liquid composites can be found in the Means and Variances Standard Report. The mean centrifuged solid analyte values used for the BBI were adjusted from the values found in the Means and Variances Standard Report to represent the waste phase as it is found in tank 241-AZ-102. The 1999 solids composite value for each measured analyte was multiplied by the mean percent solids measurement of $85.82 \%$. The 1999 liquid composite value for the identical analyte was divided by the associated density of $1.14 \mathrm{~g} / \mathrm{mL}$, and multiplied by the percent liquid expected for the sludge $(14.18 \%)$. The sum of the two analyte values multiplied by their respective weight percent values were reported in the mean concentration for 1999 core composite solids vector. An exception for two analytes in the 1999 core composite solids vector exists. The less-than detect values measured for ${ }^{79} \mathrm{Se}$ and ${ }^{129} \mathrm{I}$ were replaced with the values reported for the 1999 core composite liquids, as the concentrations for these two soluble radionuclides were expected to be similar between the two phases.

The 1998 core samples, from core 254, were analyzed at the 222-S laboratory and the Savannah River Technical Center (SRTC). The analyses completed in the 222-S laboratory were done on a segment and a composite basis. The means calculated from the analytical results can be found in the Means and Variances Standard Report. The sample analyses done for the 1998 core segments were only completed on core 154 , segments 2,7 , and 14. Because the 222-S laboratory analyses were completed on limited segments from the sampling event, the means from the 1998 core segments were not incorporated for this BBI effort. The 1998 composite combined material from each of the core 254 segments, and the means from the 222-S laboratory 1998 core composite analyses were representative of the core sample. The results from the 1998 core composite samples supported the results from the 1999 sampling event, but did not provide any addition information. Therefore, the 222-S analyses of the 1998 core composite were not included in this BBI effort. 


\section{RPP-SD-WM-ER-411, Rev. 1}

The majority of the material from core 254 was shipped to the SRTC as eight composite samples. The samples were combined, and then the phases were separated by filtering the supernatant liquid. The percentage of solids expected in the supernatant of tank 241-AZ-102 is small, and the means from the liquids analytical results obtained from the SRTC were considered representative of the tank supernatant. The results were included as the mean concentrations for 1998 SRTC filtered liquid composite vector. Following the filtration of the samples, the solids were washed with two $50 \mathrm{~mL}$ portions of $0.01 \mathrm{M} \mathrm{NaOH}$ and dried. Because of the solids sample treatment, the SRTC analytical results reported should not be used in the BBI effort. However, since the SRTC solids results were not reported elsewhere in the autoTCR, they were incorporated as the mean concentrations for 1998 SRTC core composite dried solids vector for comparison with other reported tank data.

Hanford Defined Waste model (Agnew et al. 1997a) SMM supernate values were considered representative of the NCAW supernatant waste, and were used for constituents below the detection limits for sample data or constituents not measured in the supernatant.

The sampling events provided data for the BBI chemical constituents in the solids, but many of the radionuclides were not measured. A process knowledge vector was created to estimate the radionuclide concentrations in the sludge waste phase. The ORIGEN2 model inventory for fuel processed through PUREX during the time period of the PUREX waste additions to tank 241-AZ-102 (Wootan 1997) was the foundation for the estimated BBI solids radionuclide process knowledge vector.

The sludge phase estimated radionuclide inventories were calculated by subtracting the selected supernatant BBI inventory values for each radionuclide from the ORIGEN2 total tank radionuclide inventory for tank 241-AZ-102. Exceptions to these calculations exist for the radionuclides ${ }^{226} \mathrm{Ra}$, ${ }^{227} \mathrm{Ac},{ }^{228} \mathrm{Ra},{ }^{229} \mathrm{Th},{ }^{231} \mathrm{~Pa},{ }^{232} \mathrm{Th},{ }^{232} \mathrm{U}$, and ${ }^{233} \mathrm{U}$. These analytes were considered essentially insoluble, and the ORIGEN2 total tank radionuclide inventories were applied as the sludge phase estimated radionuclide inventories. The sludge radionuclide inventory values were divided by the tank 241-AZ-102 sludge associated density $(1.47 \mathrm{~g} / \mathrm{mL})$ and the sludge volume $(397 \mathrm{~kL})$ to obtain the radionuclide concentrations reported in the tank process knowledge estimated BBI solids radionuclide concentration vector.

The tank supernatant volume increased following the completion of the sampling events with periodic condensate additions from the AY and AZ tank farms through tank 241-AZ-151. Multipliers were applied to the supernatant sample vectors to adjust for the change in tank volume. A multiplier of $0.914(889 \mathrm{kgal} / 973 \mathrm{kgal})$ was applied to the 1998 supernatant sample vectors, as the tank volume during sampling was estimated at $3365 \mathrm{~kL}$ ( $889 \mathrm{kgal})$. In 1999, the tank volume fluctuated between $3478 \mathrm{~kL}(919 \mathrm{kgal})$ and $3524 \mathrm{~kL}$ (931 kgal) during the three months core sampling took place. A multiplier of 0.951 , calculated from the average tank volume during the 1999 sampling event ( $925 \mathrm{kgal} / 973 \mathrm{kgal})$, was applied to the 1999 segment and composite sample vectors.

For the 1999 sampling event, the supernatant density value $(1.14 \mathrm{~g} / \mathrm{mL})$ was derived from the liquid core composite mean specific gravity. A supernatant density of $1.15 \mathrm{~g} / \mathrm{mL}$ was reported for the 1998 filtered liquid composite. The mean bulk density of $1.47 \mathrm{~g} / \mathrm{mL}$ from the 1999 core segment solids was used as the associated density for the NCAW sludge sample vectors. The HDW model (Agnew et al. 1997a) 241-AZ-102 SMM inventory density was $1.05 \mathrm{~g} / \mathrm{mL}$. 


\section{RPP-SD-WM-ER-411, Rev. 1}

The total tank volume of $3,682 \mathrm{~kL}$ ( $973 \mathrm{kgal}$ ) was reported in CHG (2000) as of July 31, 2000. The July 31, 2000 manual FIC measurement of 353.9 in. supports the reported total tank volume. The total sludge volume of $397 \mathrm{~kL}$ ( $105 \mathrm{kgal})$ was calculated from the current available sludge level measurements, which recorded an average height of 38 inches. The supernatant volume was calculated by subtracting the total sludge volume from the total tank volume. The BBI volume and phase information will be reflected in a future Hanlon report update.

For calculating the BBI, the mean concentrations for 1999 data were preferred, where available. Analyte concentrations from the 1999 core segment means were preferred over the 1999 core composite means. Data from the 1998 core sampling event were available as well. When comparing mean values below detection limits, the lowest nondetected value was always selected. When comparing constituent results between analytical methods where the magnitude of the results were similar, the higher value was chosen. When neither sample or template data were available for a given analyte, or when available data were below detection limits and the detection limit was higher than the HDW model value, then HDW model results (Agnew et al. 1997a) were used.

All inventory calculations were performed using the Best-Basis Inventory Maintenance (BBIM) Tool. The updated best-basis inventory values for tank 241-AZ-102 can be found in the Best-Basis Inventory (Non-Radionuclides) and Best-Basis Inventory (Radionuclides) Standard Reports. Once the best-basis inventories were determined, the hydroxide inventory was calculated by performing a charge balance with the valences of other analytes. This charge balance approach is consistent with that used by Agnew et al. (1997a). The total uranium values for the liquid and solid composite vectors are a sum of the ${ }^{235} \mathrm{U},{ }^{236} \mathrm{U}$, and ${ }^{238} \mathrm{U}$ composite sample mean values for each phase. The inventories for other uranium isotopes were calculated using total uranium values. The inventories for americium, plutonium, and other alpha-emitting isotopes in both phases were calculated from $\mathrm{Pu}^{239 / 240}$ and $\mathrm{Am}^{241}$ sample values. 


\section{RPP-SD-WM-ER-411, Rev. 1}

\section{Reference List}

Adams, M. R., 1999, River Protection Process Engineering Desk Instruction and Guidance Manual, HNF-SD-WM-PROC-021, Rev. 3, Lockheed Martin Hanford Corporation, Richland, Washington.

Agnew; S. F., J. Boyer, R. A. Corbin, T. B. Duran, J. R. Fitzpatrick, K. A. Jurgensen, T. P. Ortiz, and B. L. Young, 1997a, Hanford Tank Chemical and Radionuclide Inventories: HDW Model Rev. 4, LA-UR-96-3860, Los Alamos National Laboratory, Los Alamos, New Mexico.

Agnew, S. F., R. A. Corbin, T. B. Duran, K. A. Jurgensen, T. P. Ortiz, and B. L. Young, 1997b, Waste Status and Transaction Records Summary (WSTRS), Rev. 4, LA-UR-97-311, Los Alamos National Laboratory, Los Alamos, New Mexico.

Babad, H., and K. S. Redus, 1994, Tank Safety Screening Data Quality Objective, WHC-SD-WM-SP-004, Rev. 0, Westinghouse Hanford Company, Richland, Washington.

Bauer, R. E. and L. P. Jackson, 1998, Data Quality Objective to Support Resolution of the Flammable Gas Issue, HNF-SD-WM-DQO-004, Rev. 3A, Duke Engineering and Services Hanford, Inc. for Fluor Daniel Hanford, Inc. Richland, Washington.

Bloom, G. R. and Q. H. Nguyen, 1996, Characterization Data Needs for Development, Design, and Operation of Retrieval Equipment Developed thought the Data Quality Objective Process, WHC-SD-WM-DQO-008, Rev. 1, Westinghouse Hanford Company, Richland, Washington.

BNFL, 2000, Interface Control Document for Waste Treatability Samples, ICD-23, BNFL-5193-ID-23, 3c.rl, BNFL Inc., Richland, Washington.

CHG, 2000, Sample Analysis/Tank Transfers, Tank Characterization Database, August 1, 2000, internet at http://twins.pnl.gov:8001/twins $3 /$ twins.htm

Dukelow, G. T., J. W. Hunt, H. Babad, and J. E. Meacham, 1995, Tank Safety Screening Data Quality Objective, WHC-SD-WM-SP-004, Rev. 2, Westinghouse Hanford Company, Richland, Washington.

Fowler, K. D. 1999, Tank Farm Waste Transfer Compatibility Program, HNF-SD-WM-OCD-015, Rev. 2, Lockheed Martin Hanford Corporation for Fluor Daniel Hanford Inc., Richland, Washington.

Hanlon, B. M., 2000, Waste Tank Summary Report for Month Ending May 31, 2000, HNF-EP-0182-146, CH2M HILL Hanford Group, Inc., Richland, Washington.

Herting, D. L., 1999, Test Plan for Retrieval Testing of Sludge from Tanks 241-AZ-101, 241-AZ-102, and 241-AY-102, HNF-5391, Rev. 0, Fluor Daniel Hanford, Inc., Richland, Washington. 
RPP-SD-WM-ER-411, Rev. 1

Johnson, G. D., 1997, Strategy for Resolution of the Flammable Gas Safety Issue, HNF-SD-WM-ER-680, Rev. 0, Duke Engineering and Services Hanford Inc. for Fluor Daniel Hanford, Inc., Richland, Washington.

Kirkbride, R. A., G. K. Allen, B. A. Higley, R. M. Orme, R. S. Wittman, J. H. Baldwin, T. W. Crawford, J. Jo, J. N. Strode, T. M. Hohl, S. L. Lambert, D. E. Place, and J. A. Seidl, 2000, Tank Farm Contractor Operation and Utilization Plan, HNF-SD-WM-SP-012, Rev. 2, CH2M HILL Hanford Group, Inc., Richland, Washington.

McCain, D. J., 1999, Results of Vapor Space Monitoring of Flammable Gas Watch List Tanks, HNF-SD-WM-TI-797, Rev. 4, Lockheed Martin Hanford Corp. for Fluor Daniel Hanford, Inc., Richland, Washington.

Nguyen, D. M., 1999a, Data Quality Objectives for TWRS Privatization Phase I: Confirm Tank T is an Appropriate Feed Source for Low-Activity Waste Feed Batch X, HNF-1796, Rev. 2, Lockheed Martin Hanford Corp. for Fluor Daniel Hanford, Inc., Richland, Washington.

Nguyen, D. M., 1999b, Data Quality Objectives for RPP Privatization Phase I: Confirm Tank T is an Appropriate Feed Source for High Level Waste Feed Batch X, HNF-1558, Rev. 2, Lockheed Martin Hanford Corp. for Fluor Daniel Hanford, Inc., Richland, Washington.

O'Rourke, J. F., 2000, Physical Property Measurements for Tanks 241-AW-103, 241-AZ-101, and 241-AZ-102, (Internal memorandum 8D500-JFO-00-011 to F. H. Steen, March 2), Fluor Global Services, Richland, Washington.

Patello, G. K., M. J. Truex, and K. D. Wiemers, 1999, Low-Activity Waste and High-Activity Waste Feed Processing Data Quality Objectives, PNNL-12163, Rev. 0, Pacific Northwest National Laboratory, Richland, Washington.

Person, J. C., 1999, Test Plan for Tank 241-AZ-102 Solubility Screening Tests, HNF-4571, Rev. 0, Fluor Global Services, Richland, Washington.

Popitti, J. A., 1999a, Contract No. DE-AC-06-96RL13200 - Additional Analysis of Double-Shell Tanks 241-AZ-101 and 241-AZ-102 for Americium-241, (Memorandum 99-PDD-047 to R. D. Hanson, June 10), United States Department of Energy Office of River Protection, Richland, Washington.

Popitti, J. A., 1999b, Contract No. DE-AC06-99RL14047 - Authorization to Modify and Delay Americium-241 (Am-241) Analysis on Double-Shell Tank (DST) 241-AZ-102, (Memorandum 99-PDD-087 to M. P. DeLozier, October 27), United States Department of Energy Office of River Protection, Richland, Washington.

Rasmussen, J. H. E., 1998, Tank 241-AZ-102 Push Mode Core Sampling and Analysis Plan, HNF-3421, Rev. 0, Lockheed Martin Hanford Corporation for Fluor Daniel Hanford, lnc., Richland, Washington.

Rasmussen, J. H. E., 2000a, Tank 241-AZ-102 Privatization Push Mode Core Sampling and Analysis Plan, HNF-4577, Rev. 4, CH2M HILL Hanford Group, Inc., Richland, Washington. 


\section{RPP-SD-WM-ER-411, Rev. 1}

Rasmussen, J. H. E., 2000b, Assessment of Tank 241-AZ-102 Composite Samples, (Memorandum 74B 100-00-002 to J. H. Baldwin, January 18), CH2M HILL Hanford Group, Inc., Richland, Washington.

Rasmussen, J. H. E., 2000c, Disposition of "See Caveat-Awaiting Action" Review Status Comments for Tank 241-AZ-102, (Memorandum 74B10-00-009 to R.A. Bechtold, pending), CH2M HILL Hanford Group, Inc., Richland, Washington.

Reynolds, D. A., W. T. Cowley, J. A. Lechelt, and B. C. Simpson, 1999, Evaluation of Tank Data for Safety Screening, HNF-4217, Rev. 0, Lockheed Martin Hanford Corporation for Fluor Daniel Hanford, Inc., Richland, Washington.

Ryan, G. W., and T. T. Tran, 1995, Tank Characterization Report for Double-Shell Tank 241-AZ-102, WHC-SD-WM-ER-411, Rev. 0, Westinghouse Hanford Company, Richland, Washington.

Steen, F. H., 2000a, Tank 241-AZ-102, Cores 254, 261, 262, and 268 Analytical Results for the Final Report, HNF-1697, Rev. 0, Fluor Hanford, Inc., Richland Washington.

Steen, F. H., 2000b, Final Analyses Results for Tank 241-AZ-102 Solid Samples, (Memorandum FH-0000747 to J. G. Field, February 11), Fluor Hanford, Inc., Richland, Washington.

Wootan, D. W., 1997, DKPRO Runs for Tank Inventories, (Memorandum FDNW-ENI-98-006 to R. A. Watrous, December 29) Fluor Daniel Northwest, Inc., Richland, Washington. 